\title{
A revision of the family Sematophyllaceae (Bryophyta) in southern Africa
}

\author{
Paulo E.A.S. Câmara, Jacques van Rooy, \\ Micheline Carvalho Silva \& Robert E. Magill
}

A revision of the family Sematophyllaceae (Bryophyta) in southern Africa. - Acta Mus. Siles. Sci. Natur., 68: 157-174, 2019.

\begin{abstract}
In the Flora of southern Africa area, comprising the countries of South Africa, Namibia, Botswana, Lesotho and Swaziland, the moss family Sematophyllaceae consists of three genera (Trichosteleum, Donnellia and Sematophyllum) and nine species. Core sematophyllous taxa with collenchymatous exothecial cells, long rostrate operculum, linear leaf cells and differentiated alar cells are included in the family. Meiothecium fuscescens is transferred to Donnellia and a new combination made. Sematophyllum wageri is reduced to synonymy under S. brachycarpum and a lectotype is designated for S. dregei. Each species is described and its distribution mapped.
\end{abstract}

Keywords: Taxonomy, distribution, southern Africa, Sematophyllaceae

\section{Introduction}

Sematophyllaceae, a mostly pantropical family, was initially described as tribus Sematophyllae by Mitten (1869) and raised to family rank by Brotherus (1908).

The family has not yet been revised on a worldwide basis, but is believed to have among 20-30 genera, being more than two thirds oligo- or monotypic (Buck \& Tan 1989, Tan \& Jia 1999) and about 200 species. Sematophyllaceae (sensu Frey \& Stech 2009; Goffinet et al. 2009) is the third largest family of pleurocarpous mosses and probably the most widespread one in the tropics. Even being relatively easy to recognize at family level, the generic boundaries are not clear. According to Buck \& Tan (1989), more than $70 \%$ of the specimens deposited in Asian herbaria are misidentified.

The first molecular studies on Sematophyllaceae (Tsubota et al. 2001a, b), found that the Sematophyllaceae include two sister clades: the core sematophyllaceous taxa and a clade named by Tsubota et al. (2001a) as "the Brotherella lineage".

As the "Brotherella lineage" lacks most (or all) of the features considered typical of Sematophyllaceae it was consequently described as the new family Pylaisiadelphaceae (Goffinet \& Buck 2004) helping to better circumscribe both family boundaries.

According to Carvalho-Silva et al. (2017), with the use of eight molecular markers, the core Sematophyllaceae (sensu strictu) is monophyletic but many of its genera, including the type genus Sematophyllum Mitt., are not and some new genera were described to accommodate the segregates.

In this paper we follow the system of classification for Sematophyllaceae by Goffinet et al. (2009) and Frey \& Stech (2009). Consequently the Sematophyllaceae can be recognized as plants with collenchymatous exothecial cells (Fig.1), long rostrate operculum, linear leaf cells and developed alar cells (Fig. 2). The Pylaisiadelphaceae will be treated separately.

The family Sematophyllaceae was last revised for southern Africa by Sim (1926). He recognised the genera Meiothecium Mitt. (1 species), Rhaphidorrhynchium Besch. ex M. Fleisch. (3 species), Sematophyllum Mitt. (4 species) and Trichosteleum Mitt. (1 species). In their annotated checklist The bryophytes of southern Africa, Magill \& Schelpe (1979) added the genera Heterophyllium (Schimp.) Müll. Hal. ex Kindb. (2 species) and Wijkia H.A. Crum (1 species). They also transferred the three species of Rhaphidorrhynchium recognised by Sim 
(1926) to Sematophyllum. This list was kept unchanged for the landmark Plants of southern Africa: names and distribution (Van Rooy 1993).

In the most recent checklist of southern African mosses (Van Rooy 2003), the two species of Heterophyllium were moved to Rhacopilopsis Renauld \& Cardot of the family Hypnaceae and Leptoischyrodon congoanus Dixon, previously treated in the family Fabroniaceae, was added to the list of Sematophyllaceae. With the addition of Gammiella ceylonensis (Broth.) B.C. Tan \& W.R. Buck in the latest moss checklist for the country of South Africa (Van Rooy 2006), and a new species of Sematophyllum described by Câmara \& Van Rooy (2014), six genera and 13 species of Sematophyllaceae were accepted for the region up to this revision.

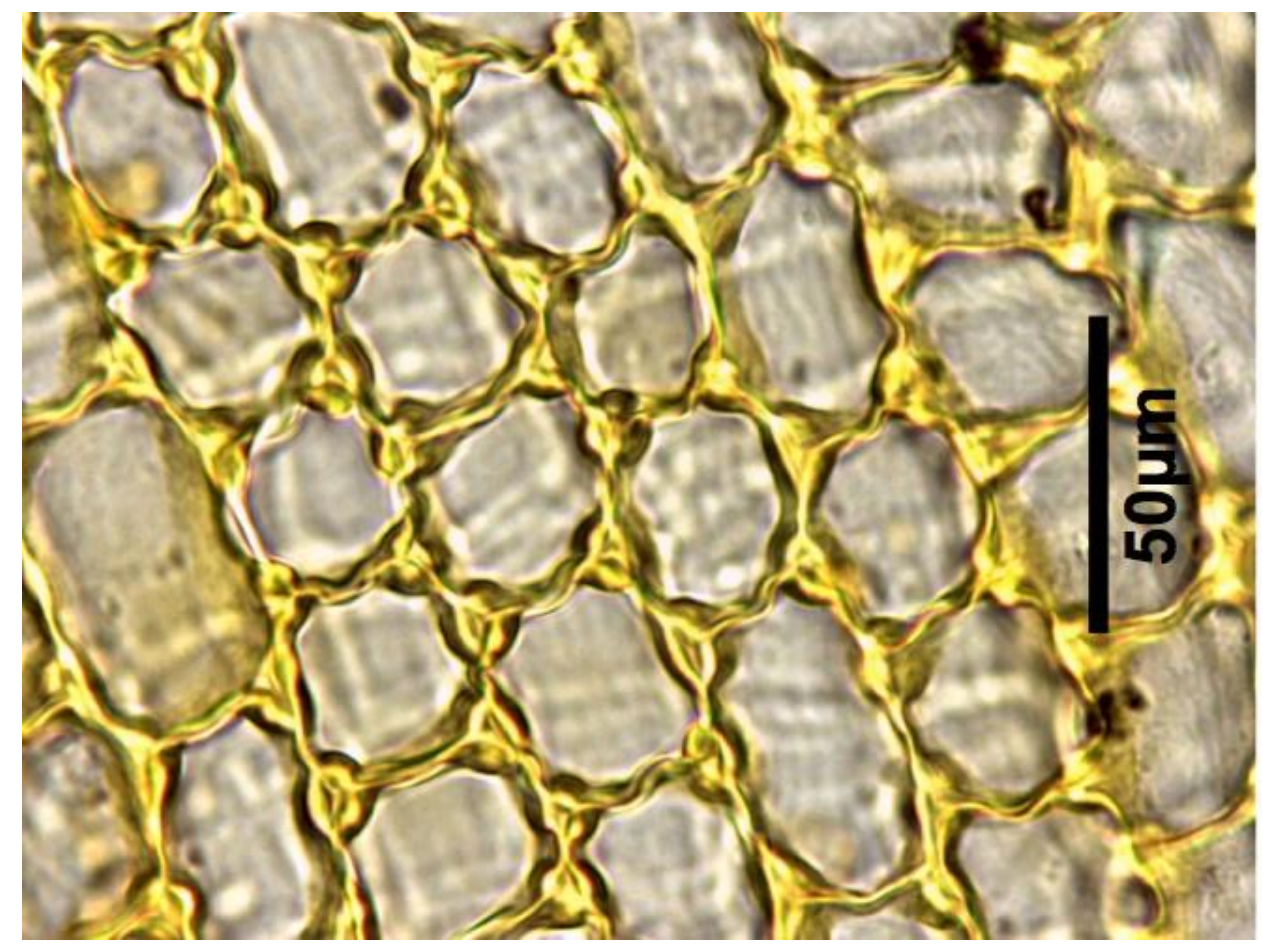

Fig 1: Collenchymatous exothecial cells, a typical feature of Sematophyllaceae and considered as a putative synapomorphy. From Wager CH568 (Sematophyllum brachycarpum).

\section{Material and Methods}

A total of 610 specimens from four different herbaria were studied (BM, L, MO and PRE). Specimens were rehydrated in water and mounted in Hoyer's solution (Anderson 1954) when needed. Type species were located by checking the protologues against label data, most of those were studied during our visit to herbarium BM. Measurements and illustrations were made from micropreparations of leaves taken from the middle of the stem. Species are recognized on the basis of morphological differences and are presented in alphabetical order of genera and species.

The morphological terms used here follow Gradstein et al. (2001) and Magill (1990). For the alar cells we follow the definition by Tan \& Jia (1999), who recognized three main types: acroporioid, heterophyllioid and brotherelloid. The South African species only represent the acroporioid and heterophyllioid types (Fig. 2).

Author abbreviations follow Brummit and Powell (1992) and abbreviations of journals follow BPH (Lawrence et al. 1968). Geographical distribution in southern Africa is based on the specimens studied while worldwide distribution is based on literature (Magill \& Schelpe 1979; O’Shea 2006). The study area comprises the Flora of Southern Africa (FSA) area, or the countries of South Africa, Namibia, Botswana, Lesotho and Swaziland. South African Provinces are those currently recognised, however for the localities (i.e below Provinces), we decided to cite the original names as they appear on the labels. For pratical purposes, only one specimen is cited for each locality. For the sake of brevity, the lists of 'Representative specimens examined' have been gathered in Appendix. 
As this is not a monograph or a taxonomic review, we are aware that some of the names may change as the genera are taxonomically revised in the future and we did not check all the synonyms and their types and do not provide taxonomic comments on them.

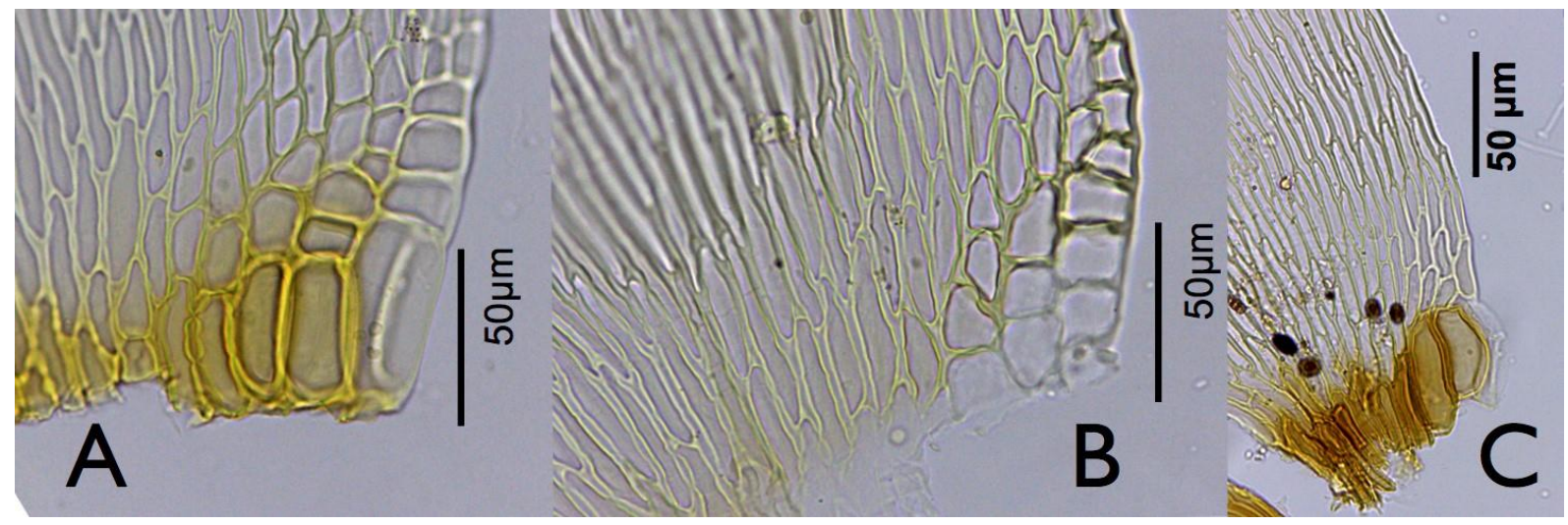

Fig 2: A, B: Heterophyllioid alar cells in Sematophyllum brachycarpum; A and B represent variations found within the same individual. C: Acroporioid alar cells in Sematophyllum zuluense.

A \& B from Wager CH568, C from Sim 10285, both PRE.

\section{Results}

There are three genera and 9 species of Sematophyllaceae in southern Africa.

\section{Key to Genera}

1. Leaf cells papillose in at least some leaves

3. Trichosteleum

1. Leaf cells smooth.... 1. Donnellia

2. Alar cells not inflated, margin cells quadrate 2. Sematophyllum

2. Alar cells inflated, margin cells linear

\section{Donnellia Austin, Bull. Torrey Bot. Club 7(2): 15-16. 1880.}

Donnellia fuscescens (A. Jaeger ex Paris) P. Câmara \& M. Carvalho-Silva, comb. nov. Meiothecium fuscescens (A. Jaeger ex Paris) Broth., Nat. Pflanzenfam. I(3): 1103. 1908. Pterogoniella fuscescens A. Jaeger ex Paris, Index Bryol. 1047. 1898. - TYPE: [South Africa]. Promontorium Bonae Spei, Bergius s.n. (isotypes: BM!). =Neckera fuscescens Müll. Hal., Syn. Musc. Frond. 2: 77. 1850. Invalid.

Plants golden green to pale green. Stems creeping, freely branched, central strand absent. Pseudoparaphyllia absent. Stem and branch leaves similar, erect, homomallous, lanceolate to ovate-lanceolate, concave, 1.00-1.32 mm long, 0.30-0.52 mm wide; margins entire; apex acute; costae absent or short and double; laminal cells longlinear, smooth, 1.0-1.5 mm long, $0.35-0.56 \mathrm{~mm}$ wide; margin cells slightly differentiated, rectangular, apex cell rhomboidal and smaller than the mid leaf cells, 54-67 $\mu \mathrm{m}$ long, 7-11 $\mu \mathrm{m}$ wide; alar region developed, colored, alar cells consisting of 2-3 rows, enlarged, sometimes inflated, colored, supra alar cells consisting of 2-3 rows, quadrate to rectangular. Asexual propagule absent. Autoicous. Perichaetial leaves erect, lanceolate, plane or slightly concave, 0.6-1.7 mm long, 0.3-0.4 mm wide, apex acute to acuminate; costae short and double or absent, laminal cells linear, smooth, 40-60 $\mu \mathrm{m}$ long, ca. 9-12 $\mu \mathrm{m}$ wide; alar cells poorly differentiated. Setae elongate, smooth, 1.5-2.0 cm long; capsules erect to suberect, cylindric to urceolate, $0.7-1.0 \mathrm{~mm}$ long; exothecial cells collenchymatous; annulus present, operculum obliquely long-rostrate; exostome caducous, with zig-zag line, furrowed, cross-striate below, coarsely papillose above, hyaline tip, trabeculate at back; endostome caducous, with high basal membrane, keeled, not perforated, cilia absent. Spores spherical, finely papillose, 15-20 $\mu \mathrm{m}$ across. Calyptrae not seen.

Distribution and habitat: Occurs as epiphyte or on decaying logs. Endemic to southern Africa, Donnellia fuscescens is infrequently collected in the Limpopo, Mpumalanga, Gauteng, Free State, KwaZulu-Natal and Western Cape Provinces of South Africa as well as Swaziland. It is fairly widespread in the Drakensberg Domain, the northern subdivision of Van Rooy \& Van Wyk's (2010) Afromontane Region, but only known from the George-Knysna and Table Mountain areas in the southern subdivision, the Cape Domain. Fig. 3. 


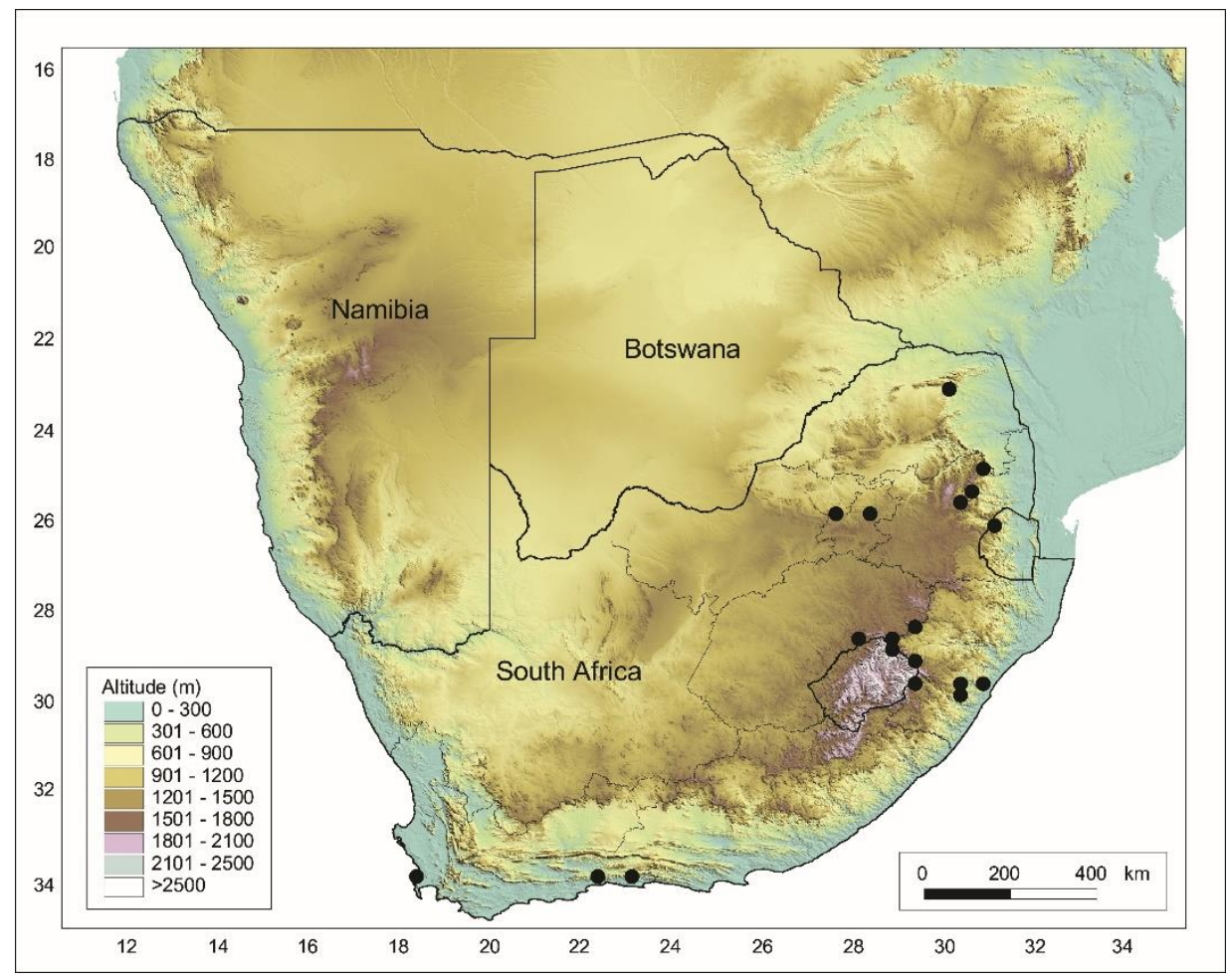

Fig 3: Distribution map for Donnellia fuscescens (A. Jaeger ex Paris) P. Câmara \& M. Carvalho-Silva.

Discussion: Southern African specimens were identified as Meiothecium fuscescens, but the alar region of the leaves is different and we can see the complete peristome, although sometimes caducous. Donnellia fuscescens is characterized by the concave, lanceolate to ovate-lanceolate leaves with apical cells smaller than central cells and the alar region disctinct, with quadrate cells. These specimens sometimes look like Donnellia commutata from the neotropics, but the setae in Donnellia fuscescens are longer and the exostome is different.

Representative specimens examined: see Appendix.

\section{Sematophyllum Mitt., J. Linn. Soc., Bot. 8: 5. 1864}

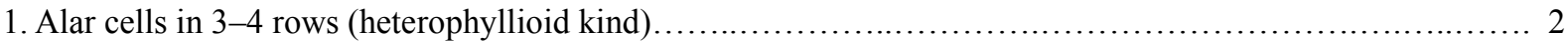

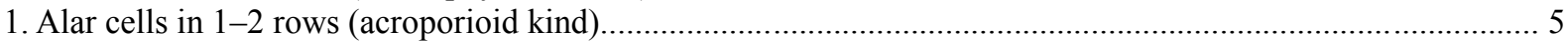

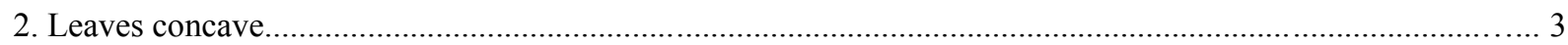

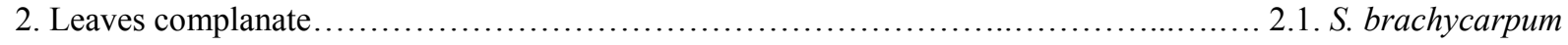

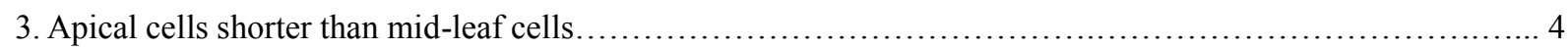

3. Apical cells same size as mid-leaf cells........................................................................ 2.5. S. sphaeropyxis

4. Leaves $0.7-1.2 \mathrm{~mm}$ long, alar cells enlarged, colored ...................................... 2.6. S. subpinnatum

4. Leaves $1.9-2.2 \mathrm{~mm}$ long, alar cells poorly developed................................. 2.4. S. magillianum

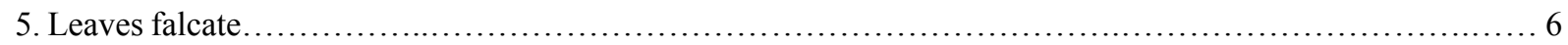

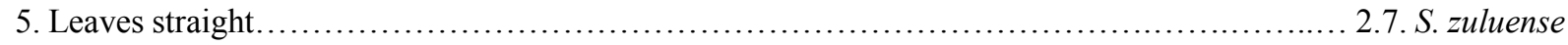

6. Leaf apex long-acuminate, pointed, leaves $0.2-0.3 \mathrm{~mm}$ wide................................ 2.2. S. dregei

6. Leaf apex short-acuminate, blunt, leaves $0.3-0.4 \mathrm{~mm}$ wide ............................. 2.3. S. gueinzii

2.1. Sematophyllum brachycarpum (Hampe) Broth., Nat. Pflanzenfam. 11: 431. 1925.

Hypnum brachycarpum Hampe, Icon. Musc. 11. 1844. Rhaphidostegium brachycarpum (Hampe) A. Jaeger, Ber. Thätigk. St. Gallischen Naturwiss. Ges. 1876-77: 396 (Gen. Sp. Musc. 2: 462). 1878. Stereodon brachycarpus (Hampe) Mitt., J. Proc. Linn. Soc. 4: 87. 1859. —TYPE: South Africa, Pappe s.n. (holotype and isotype at BM!). $=$ Sematophyllum wageri C.H. Wright ex Wager, Trans. Roy. Soc. South Africa 4: 5. 2 c. 1914. Rhaphidostegium wageri (C.H. Wright ex Wager) Dixon, Trans. Roy. Soc. South Africa 18: 260. 1929. _TYPE: Van Reenen, Wager CH568 (holotype: PRE!). Syn. Nov. Figure 15A. 
Plants small, golden green to pale green. Stems creeping, freely branched, central strand absent. Pseudoparaphyllia absent. Stem and branch leaves similar, erect, complanate, ovate-lanceolate, plane, 1.20$1.35 \mathrm{~mm}$ long, $0.25-0.47 \mathrm{~mm}$ wide; margins entire; apex acuminate; costae absent; laminal cells linear, smooth, 45-74 $\mu \mathrm{m}$ long, 5.0-8.5 $\mu \mathrm{m}$ wide; alar cells enlarged, not inflated, sometimes colored, consisting of 3-4 rows. Asexual propagule absent. Autoicous. Perichaetial leaves erect, lanceolate or ovate-lanceolate, plane, 1.0-1.6 $\mathrm{mm}$ long, $0.25-0.47 \mathrm{~mm}$ wide, apex acuminate to acute; costae short and double or absent, laminal cells linear, quadrate near base, smooth, 75-80 $\mu \mathrm{m}$ long, ca. 9-13 $\mu \mathrm{m}$ wide; alar cells poorly differentiated or absent. Setae elongate, smooth, ca. $0.6 \mathrm{~cm}$ long; capsules erect, ovoid-cylindric, $0.7-1.0 \mathrm{~mm}$ long, constricted below mouth when dry; exothecial cells collenchymatous; annulus present, operculum obliquely long-rostrate; exostome with zig-zag line, cross-striate below, coarsely papillose above, trabeculate at back; endostome with high basal membrane, keeled, cilia not seen. Spores spherical, finely papillose, 12-20 $\mu \mathrm{m}$ across. Calyptrae cucullate, naked, smooth.

Distribution and habitat: Occurs as an epiphyte, or occasionally on soil or rock, from sea level up to $1900 \mathrm{~m}$. It is widely distributed throughout the Afromontane Region of Van Rooy \& Van Wyk (2010) and therefore classified by them (Van Rooy \& Van Wyk 2011) in the Widespread Afromontane Subelement, a subdivision of the Afromontane Forest Element. Outside southern Africa it occurs in Kenya, Mozambique, Uganda, Zambia and Zimbabwe. Fig. 4.

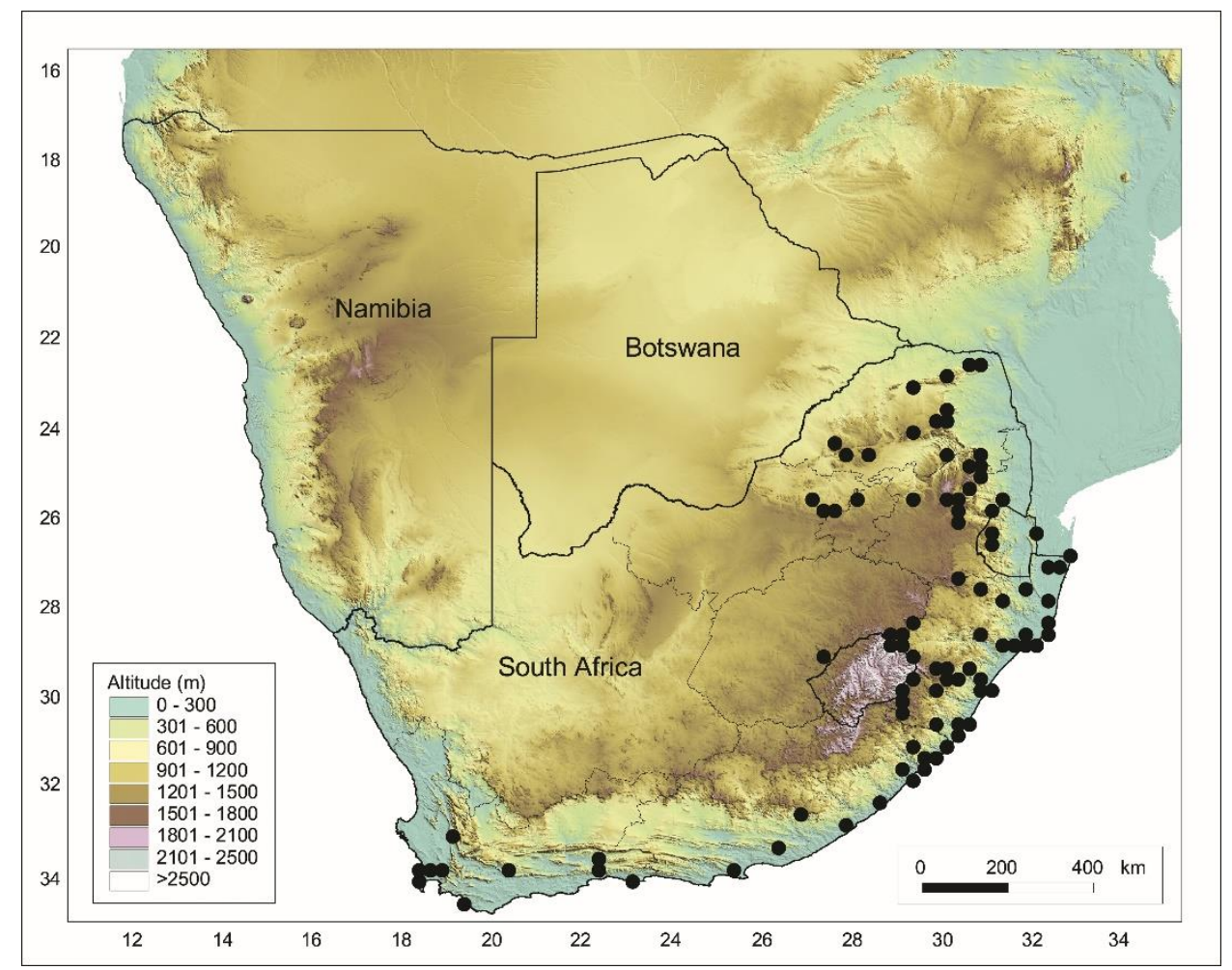

Fig 4: Distribution map for Sematophyllum brachycarpum (Hampe) Broth.

Discussion: By far the most common and widespread species of Sematophyllum in southern Africa. Gametophycically, this species resembles the widespread American Donnellia commutata (Müll. Hal.) W.R. Buck, but as it is frequently found fertile, the sporophyte differences will separate them easily. Under this name we are synonymizing the more rare Sematophyllum wageri (with only a few collections known to us). After the study of both types it seems that the confusion may have been caused by the the wide variablility of the alar cells. Usually plants with a colored and more developed alar region were named as $S$. wageri, whereas the less deveopled, colorless alar region has been associated with $S$. brachycarpum. However, both types of alar cells can be found in the very same individual (Fig. 2 A and B). As all other morphological differences overlap, we decided to treat them as a single species.

Representative specimens examined: see Appendix. 
2.2. Sematophyllum dregei (Müll. Hal.) Magill, Mem. Bot. Surv. S. Africa 43: 7. 1979.

Hypnum dregei Müll. Hal., Syn. Musc. Frond. 2: 311. 1851. Cupressina dregei (Müll. Hal.) Müll. Hal., Hedwigia 38: 146. 1899. Rhaphidorrhynchium dregei (Müll. Hal.) Broth., Nat. Pflanzenfam. 11: 427. 1925. Rhaphidostegium dregei (Müll. Hal.) A. Jaeger, Ber. Thätigk. St. Gallischen Naturwiss. Ges. 1876-77: 407 (Gen. Sp. Musc. 2: 473). 1878. -TYPE: [South Africa] Promontorium Bonae Spei, Drege [8040] (Lectotype designated here: BM!; isolectotype: L!); Prope Phillipstown, Gueinzius s.n.; Prope Zwellendam, Pappe s.n. (syntypes not found). Illustration Fig. 12B.

Plants small, golden green to pale green. Stems creeping, freely branched, central strand absent. Pseudoparaphyllia absent. Stem and branch leaves similar, falcate, lanceolate, plane, 1.0-1.6 mm long, 0.2-0.3 mm wide; margins entire; apex long-acuminate, serrate; costae absent; laminal cells linear, smooth, 47-71 $\mu \mathrm{m}$ long, 3-4 $\mu \mathrm{m}$ wide; alar cells enlarged, inflated, usually not colored, consisting of 1 row. Asexual propagule absent. Autoicous. Perichaetial leaves erect, linear-lanceolate, plane, 1.3-2.2 mm long, 0.30-0.45 mm wide, apex acuminate to aristate, serrulate; costae absent or short and double, laminal cells linear, smooth, porose, 67-77 $\mu \mathrm{m}$ long, 4-5 $\mu \mathrm{m}$ wide, quadrate near base; alar cells enlarged, inflated usually colored. Setae elongate, smooth, ca. $1 \mathrm{~cm}$ long; capsules inclined to pendent, ovoid-cylindric, ca. $1 \mathrm{~mm}$ long, constricted below mouth when dry; exothecial cells collenchymatous; annulus present, operculum obliquely long-rostrate; exostome with zig-zag line, cross-striate below, coarsely papillose above, trabeculate at back; endostome with high basal membrane, keeled, cilia absent. Spores spherical, finely papillose, 19-21 $\mu \mathrm{m}$ across. Calyptrae cucullate, naked, smooth.

Distribution and habitat: Grows as epiphyte or on decaying logs or rarely on rock, from sea level up to $3069 \mathrm{~m}$ high in the Drakensberg range. Another species of the Widespread Afromontane Subelement (Van Rooy \& Van Wyk 2011), S. dregei is widespread throughout the Afromontane region of South Africa, except Gauteng Province. Outside South Africa, it occurs in Kenya, Malawi, Swaziland, Tanzania, Zimbabwe and Namibia. Fig. 5.

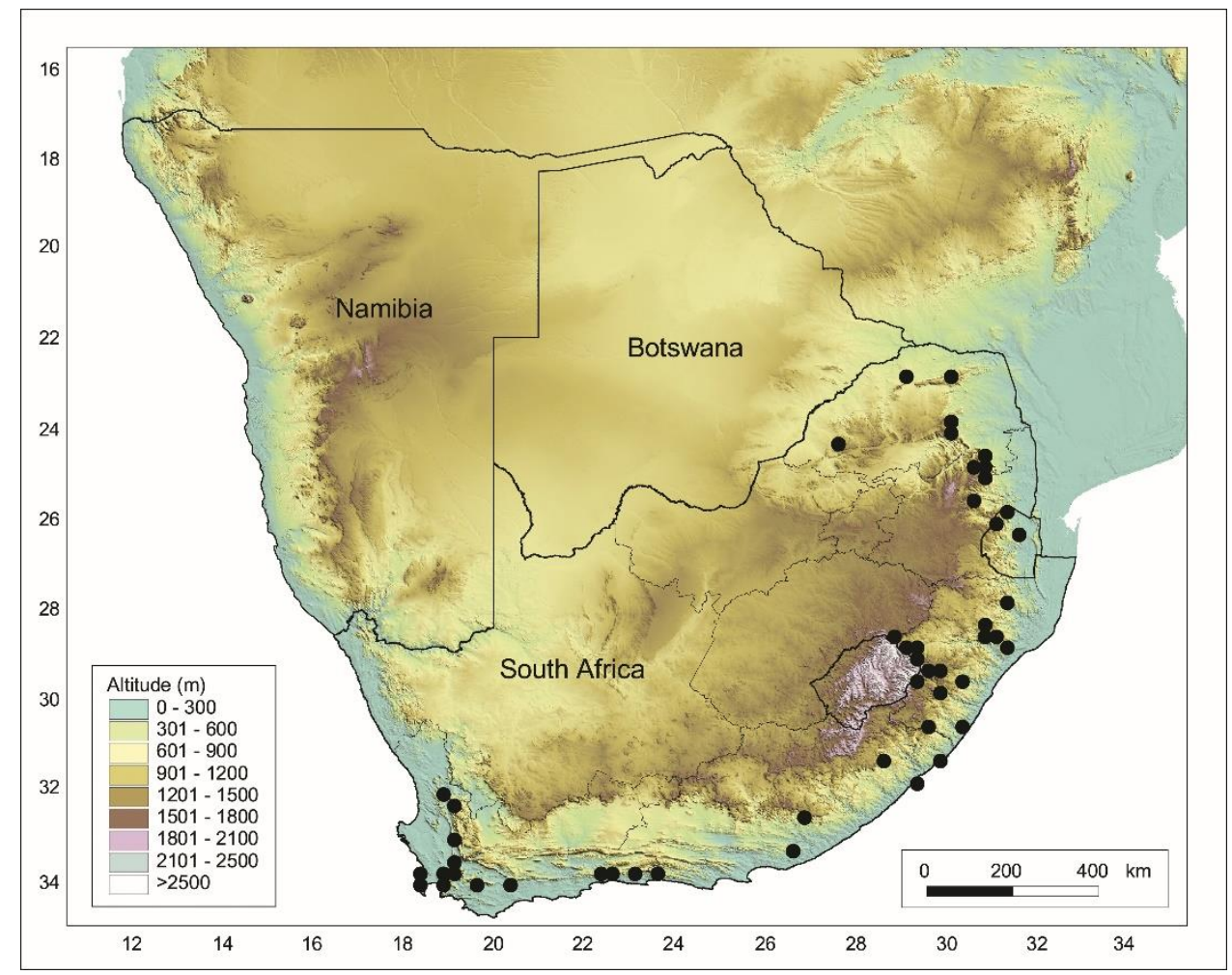

Fig 5: Distribution map for Sematophyllum dregei (Müll. Hal.) Magill

Discussion: This species resembles $S$. gueinzii, indeed they seem to be very close and are somewhat difficult to tell apart. We decided to keep them separate based on the wider leaf shape of $S$. gueinzii as well as differences in its apex shape and serrulation, as $S$. dregei has a more narrowly pointed apex (Fig. 6). The porose cells (found on both) and alar cell region resemble some new world species of Acroporium.

Representative specimens examined: see Appendix. 


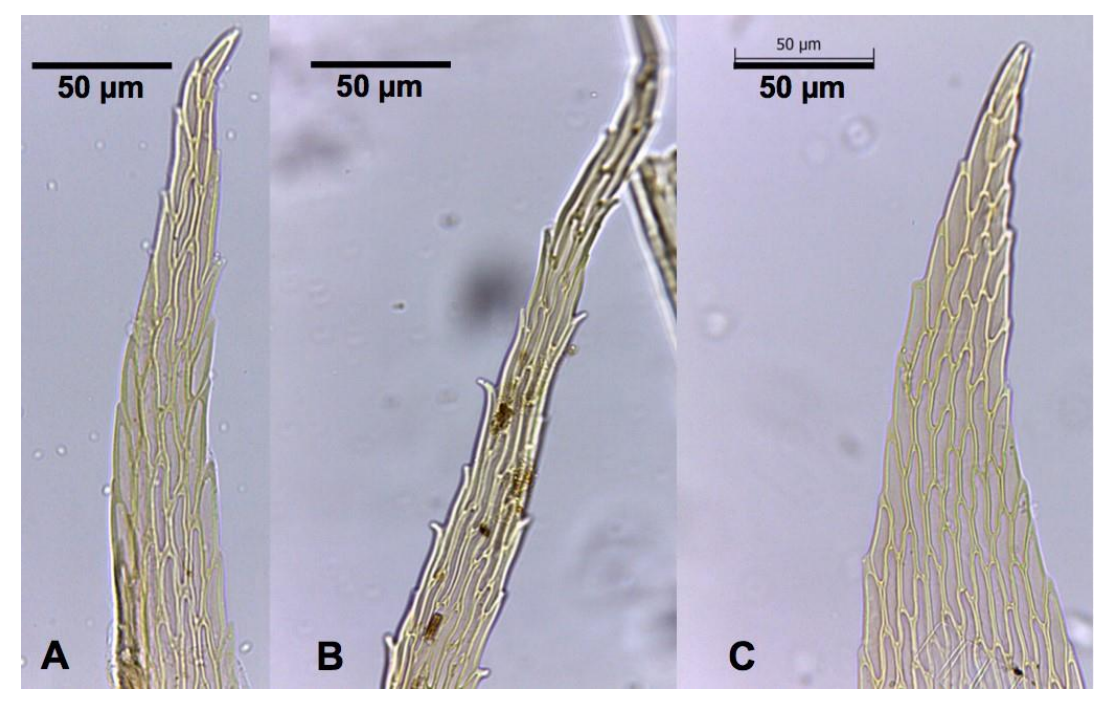

Fig 6: Leaf apex differences between Sematophyllum dregei (A and B) and S. gueinzii (C). A and B from Drege [8040] (BM) and C from Pappe s.n. (BM).

\subsection{Sematophyllum gueinzii (Hampe) Magill, Mem. Bot. Surv. S. Africa 43: 7. 1979.}

Hypnum gueinzii Hampe, Icon. Musc. 12. 1844. Rhaphidorrhynchium gueinzii (Hampe) Broth., Nat. Pflanzenfam., 11: 428. 1925. Rhaphidostegium gueinzii (Hampe) A. Jaeger, Ber. Thätigk. Gallischen Naturwiss Ges. 1876-77: 407 (Gen. Sp. Musc. 2: 473). 1878. - TYPE: South Africa, Pappe s.n. (holotype and isotype at BM!). Fig 12 C.

Plants small, golden green to pale green. Stems creeping, freely branched, central strand absent. Pseudoparaphyllia absent. Stem and branch leaves similar, erect, ovate-lanceolate, plane, falcate, 0.9-1.4 mm long, 0.31-0.40 mm wide; margins entire; apex short-acuminate, rarely serrulate at very apex; costae short and double; laminal cells linear, smooth, 50-71 $\mu \mathrm{m}$ long, 6.0-7.0 $\mu \mathrm{m}$ wide; alar cells enlarged, inflated, colored, consisting of 1 row. Asexual propagule absent. Autoicous. Perichaetial leaves erect, lanceolate, plane, 1.8-2.0 $\mathrm{mm}$ long, ca. $0.41 \mathrm{~mm}$ wide, apex acuminate, serrulate; costae absent, laminal cells linear, quadrate near base, smooth, 60-80 $\mu \mathrm{m}$ long, 4.5-5.5 $\mu \mathrm{m}$ wide; alar cells enlarged, not inflated. Setae elongate, smooth, $0.8-1.0 \mathrm{~mm}$ long; capsules inclined, ovoid-cylindric, ca. 1.0-1.5 mm long, constricted below mouth when dry; exothecial cells collenchymatous; annulus present, operculum obliquely long-rostrate; exostome with zig-zag line, cross-striate below, coarsely papillose above, trabeculate at back; endostome with high basal membrane, keeled, cilia absent. Spores spherical, finely papillose, 12-14 $\mu \mathrm{m}$ across. Calyptrae cucullate, naked, smooth.

Distribution and habitat: Occurs as epiphyte or on decaying logs from sea level up to $2000 \mathrm{~m}$, very few specimens were found up to $3000 \mathrm{~m}$ in the Drakensberg range. Widespread throughout the Afromontane Region, the species is most frequently collected in the Eastern and Western Cape Provinces. Outside southern Africa, it occurs in Zimbabwe. Fig. 7.

Discussion: This species resembles $S$. dregei, see comments there.

Representative specimens examined: see Appendix.

2.4. Sematophyllum magillianum Câmara, P.E.A.S. \& Van Rooy, Bryologist 117(3): 297. 2014. -TYPE: South Africa, Transvaalia: in montibus Kwatlamba supra Lydenburg, J.H. McLea sub A. Rehmann 660 (holotype: PRE!; isotypes: LW, PRE!, UB!). Figure in Câmara \& Van Rooy (2014).

Plants robust, dark green. Stems creeping, freely branched, central strand absent. Pseudoparaphyllia absent. Stem and branch leaves similar, erect, never homomallous, ovate or orbicular, concave, 1.9-2.2 mm long, 0.8-1.1 mm wide, margins entire; costae absent; cells linear, smooth, 73-80 $\mu \mathrm{m}$ long, 8.5-9.2 $\mu \mathrm{m}$ wide; alar cells in 2-3 rows, poorly developed, non-inflated and usually not colored. Asexual propagule absent. Autoicous. Perichaetial leaves erect, lanceolate to triangular, $1.7-2.5 \mathrm{~mm}$ long, $0.5-0.7 \mathrm{~mm}$ wide, acuminate, plane; costae absent, cells linear, smooth, 115-170 $\mu \mathrm{m}$ long, 11.5-13.5 $\mu \mathrm{m}$ wide; alar cells not differentiated. Setae elongate, smooth, 1.0 $1.5 \mathrm{~cm}$ long; capsules erect, ovoid-cylindric, ca. $2 \mathrm{~mm}$ long, not constricted below mouth when dry; exothecial cells collenchymatous; annulus poorly differentiated, operculum not seen; exostome teeth hyaline, on front surface with thickened zig-zag center line, plates coarsely but sparsely papillose, on back surface trabeculae not projecting, smooth, cross-striate below; endostome with high basal membrane, keeled, cilia not seen. Spores spherical, finely papillose, ca. $17 \mu \mathrm{m}$ across. Calyptrae not seen. 
Distribution and habitat: The species grows on rock in streams (occasionally submerged) and wet rock faces in wooded kloofs and forests, at elevations of 15 to $1219 \mathrm{~m}$. Endemic to South Africa, it is centered in the Midlands and coastal regions of KwaZulu-Natal and the Pondoland region of the Eastern Cape. It is also found in the Soutpansberg of Limpopo, the Drakensberg escarpment of Mpumalanga and the Magaliesberg of the North-West Province. Two collections are known from Table Mountain in the South Western Cape. Fig. 8.

Discussion: This species is mostly aquatic and herbarium specimens were frequently named as Sematophyllum caespitosum Mitt. (see Câmara \& van Rooy 2014). Sematophyllum magillianum can be easily recognized by the size of the plants and the poorly developed alar region of the leaf.

Representative specimens examined: see Appendix.

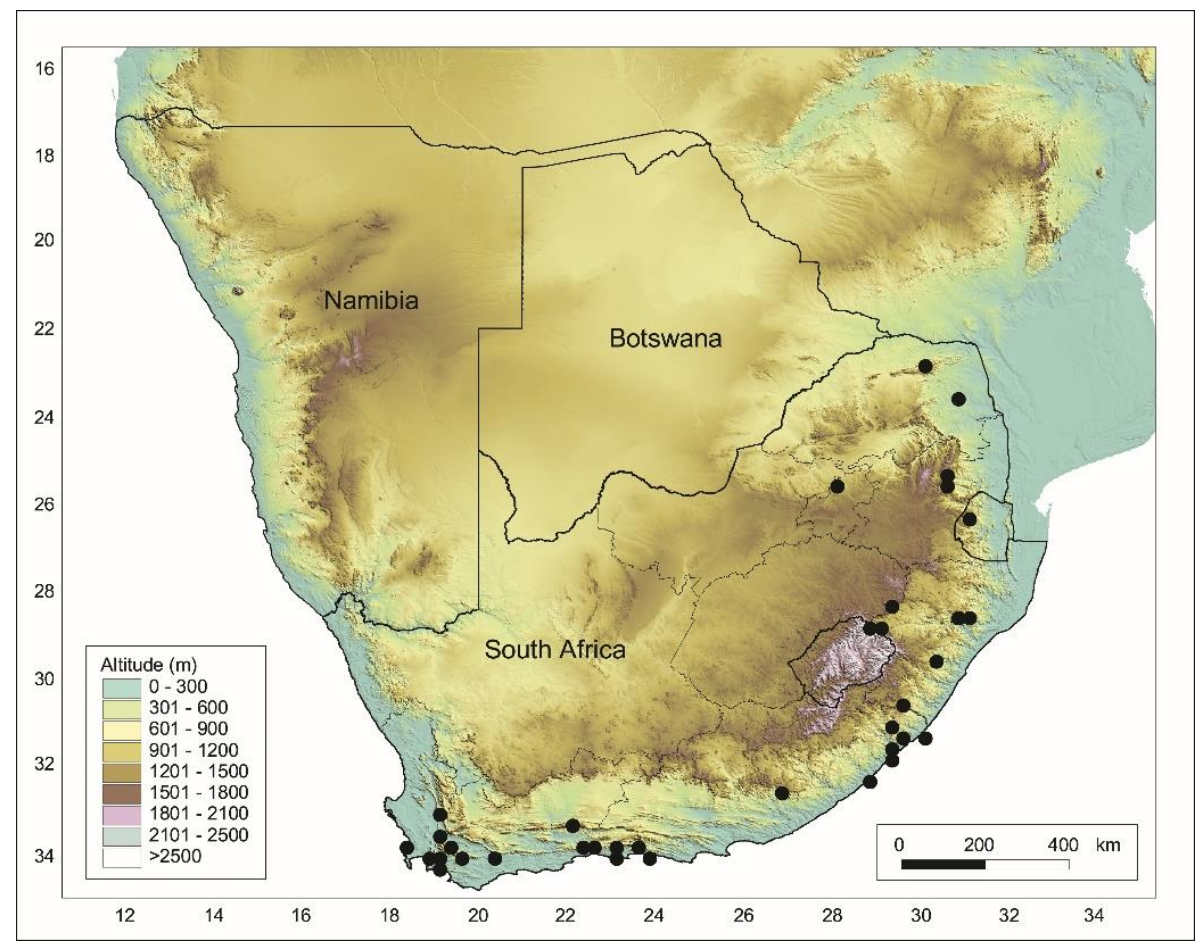

Fig 7: Distribution map for Sematophyllum gueinzii (Hampe) Magill

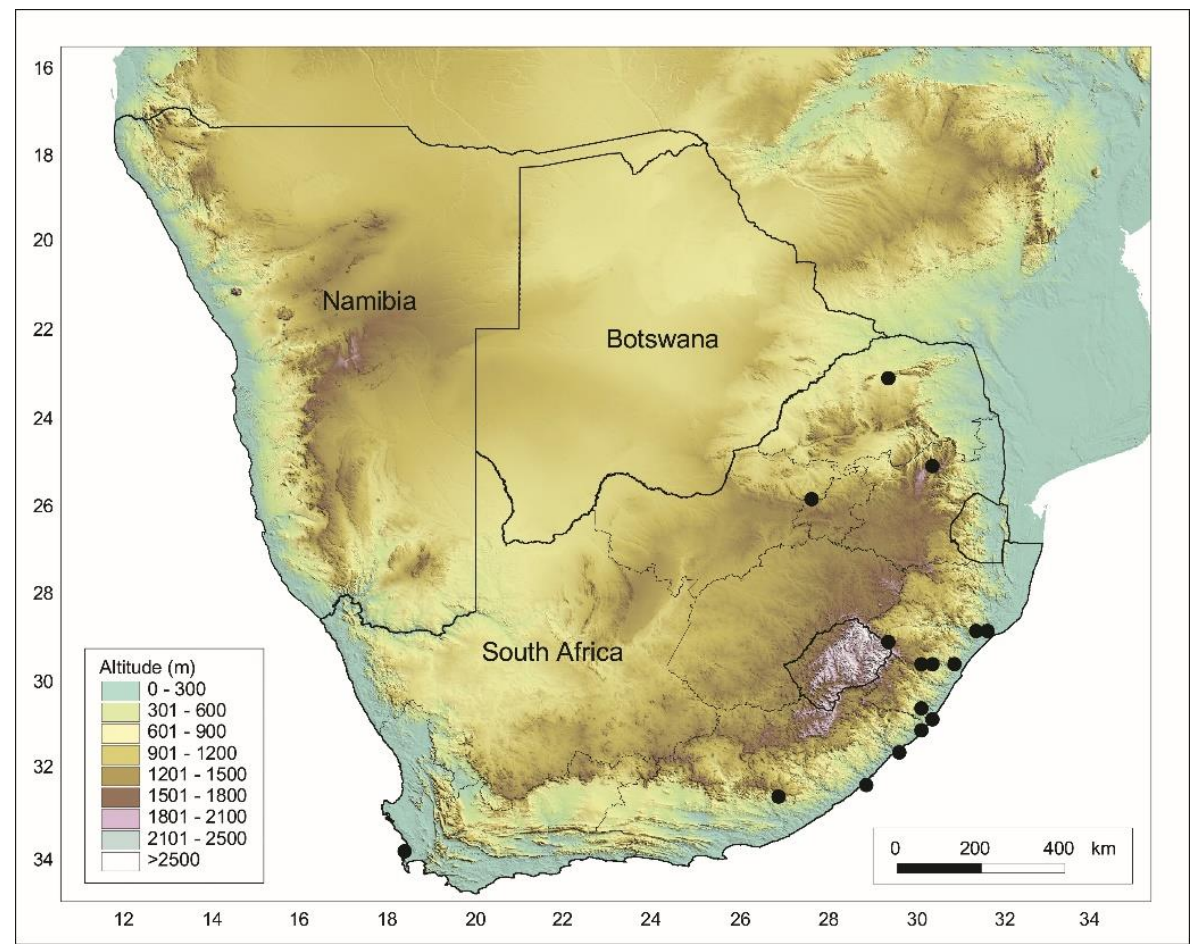

Fig 8: Distribution map for Sematophyllum magillianum Câmara \& Van Rooy. 
2.5. Sematophyllum sphaeropyxis (Müll. Hal.) Broth., Nat. Pflanzenfam. 11: 432. 1925.

Aptychus sphaeropyxis Müll. Hal., Hedwigia 38: 141. 1899. Rhaphidostegium sphaeropyxis (Müll. Hal.) Paris, Index Bryol. Suppl. 297. 1900. — TYPE: South Africa, Natal, Inchanga, Rehmann 372 (holotype at B, probably lost; isotypes: BM!, L!, PRE!). Fig 12D.

Plants small, golden green to dark green. Stems creeping, freely branched, central strand absent. Pseudoparaphyllia absent. Stem and branch leaves similar, erect, oblong-lanceolate, galeate, concave, 1.5-1.6 $\mathrm{mm}$ long, 0.38-0.46 mm wide; margins entire; apex acuminate; costae absent; laminal cells linear, smooth, 71-81 $\mu \mathrm{m}$ long, 6.0-7.5 $\mu \mathrm{m}$ wide; alar cells enlarged, not inflated, colored, consisting of 3 rows. Asexual propagule absent. Autoicous. Perichaetial leaves erect, lanceolate, plane, 1.8-2.0 mm long, 0.32-0.43 mm wide, apex acuminate, entire; costae absent, laminal cells linear, quadrate near base, smooth, 75-115 $\mu \mathrm{m}$ long, 7-10 $\mu \mathrm{m}$ wide; alar cells poorly differentiated. Setae elongate, sometimes twisted, smooth, $1.0-1.5 \mathrm{~cm}$ long; capsules erect to horizontal, ovoid-cylindric, 1-2 mm long, constricted below mouth when dry; exothecial cells collenchymatous; annulus present, operculum long-rostrate; exostome with zig-zag line, cross-striate below, coarsely papillose above, trabeculate at back; endostome with high basal membrane, keeled, perforated, cilia absent. Spores spherical, finely papillose, 15-17 $\mu \mathrm{m}$ across. Calyptrae cuculate, naked, smooth.

Distribution and habitat: The species is mostly epiphytic or on decaying logs from sea level up to $2893 \mathrm{~m}$ high in the Maloti Moutains of Lesotho. In southern Africa it is frequently collected in the northern part of the Afromontane Region (Drakensberg Domain) and infrequently in the southern part or the Cape Domain (Van Rooy \& Van Wyk 2010). Sematophyllum sphaeropyxis is also known from Zimbabwe. Fig. 9.

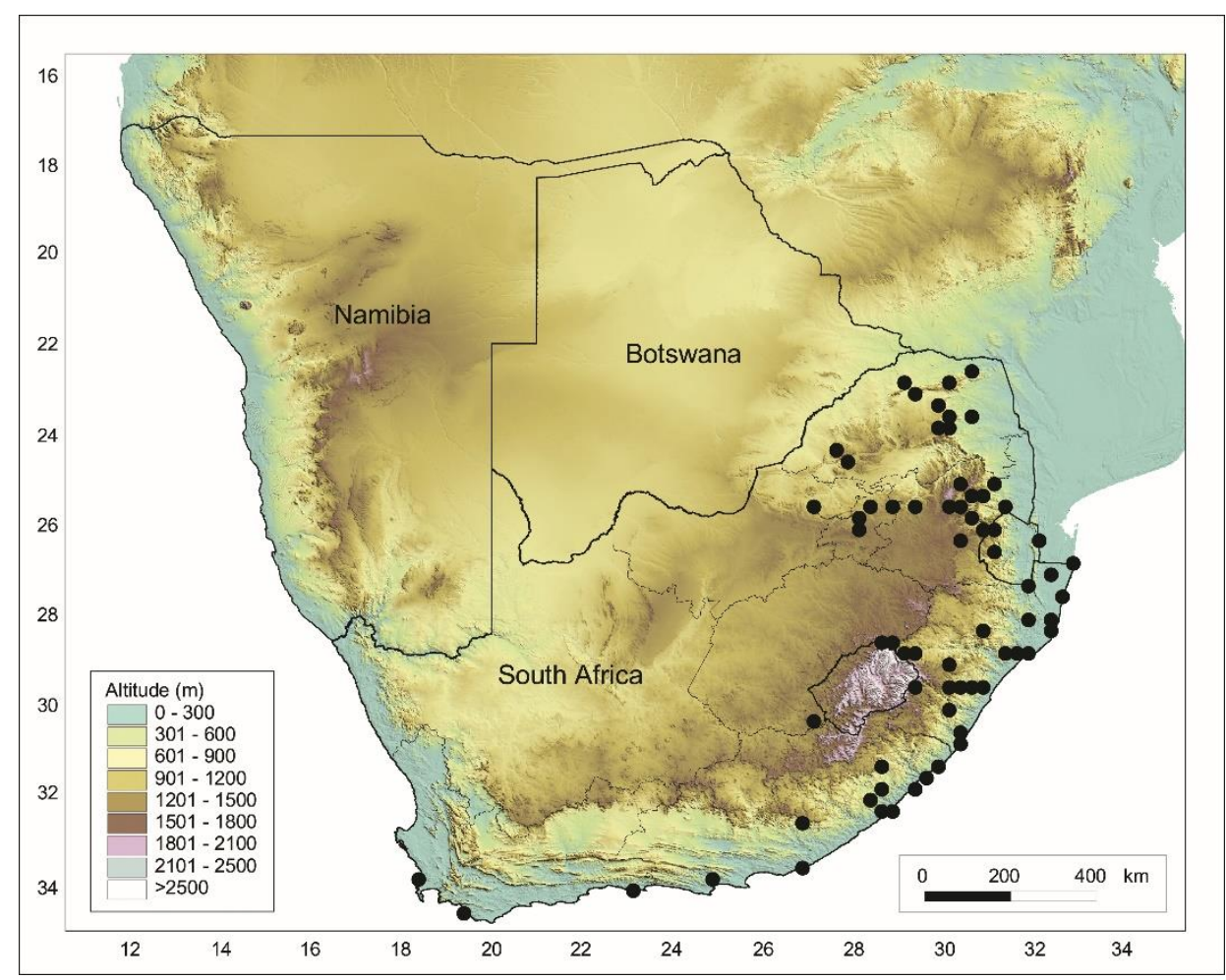

Fig 9: Distribution map for Sematophyllum sphaeropyxis (Müll. Hal.) Broth.

Discussion: With its concave and galeate leaves, this very abundant species resembles the new world Sematophyllum galipense and $S$. cuspidiferum.

Representative specimens examined: see Appendix.

\subsection{Sematophyllum subpinnatum (Brid.) E. Britton, Bryologist 21(2): 28.1918.}

Leskea subpinnata Brid., Muscol. Recent. Suppl. 2: 54. 1812. Hypnum subpinnatum (Brid.) Arn., Mém. Soc. Linn. Paris, 5: 302. 1827. Rhaphidostegium subpinnatum (Brid.) E. Britton, Bryologist 21: 28. 1918. —TYPE: In Hispaniola ad arbores habitat, Poiteau s.n. (holotype at B; isotype: NY!). =Leskea caespitosa Sw., Fl. Ind. Occid. 3: 1807. 1806. Hom. Ileg. Sematophyllum caespitosum [Sw.] Mitt., J. Linn. Soc., Bot. 12: 479.1869. Rhaphidostegium caespitosum (Mitt.) Besch., Ann. Sci. Nat., Bot., sér. 6, 3: 247. 1876. Fig. 12 E. 
Plants small to medium size, golden green to dark green. Stems creeping, freely branched, central strand absent. Pseudoparaphyllia absent. Stem and branch leaves similar, usually homomallous, ovate to oblong-ovate, concave, 0.7-1.2 mm long, 0.30-0.45 mm wide; margins entire; apex acute or short acuminate; costae absent; laminal cells linear at mid leaf becoming shorter and rhomboidal in the apex, smooth, 55-78 $\mu \mathrm{m}$ long, $6.5-8.5 \mu \mathrm{m}$ wide; alar cells enlarged, not inflated, colored, consisting of 3-4 rows. Asexual propagule absent. Autoicous. Perichaetial leaves erect, oblong-ovate, plane, $1.0-1.3 \mathrm{~mm}$ long, $0.3-0.5 \mathrm{~mm}$ wide, apex acuminate; costae absent, laminal cells long-rhomboidal, smooth, 60-112 $\mu \mathrm{m}$ long, 7-15 $\mu \mathrm{m}$ wide; alar cells not differentiated. Setae elongate, smooth, 0.5-1.0 cm long; capsules erect to suberect, short-cylindrical, ca. $1 \mathrm{~mm}$ long, constricted below mouth when dry; exothecial cells strongly collenchymatous; annulus not differentiated, operculum obliquely longrostrate; exostome with zig-zag line, cross-striate below, coarsely papillose above, trabeculate at back; endostome with high basal membrane, keeled, cilia not seen. Spores spherical, finely papillose, $15-20 \mu \mathrm{m}$ across. Calyptrae cucullate, naked, smooth.

Distribution and habitat: In the FSA area, S. subpinnatum occurs as an epiphyte or saxicolous, rarely rupicolous, from sea level up to $2174 \mathrm{~m}$. Widespread throughout the Afromontane Region of Van Rooy \& Van Wyk (2010), but absent from the Limpopo Province in the north. Outside southern Africa, the species is widespread throughout tropical and subtropical Africa. It is also widespread in the Americas, ranging from southern USA to South Brazil. Fig. 10.

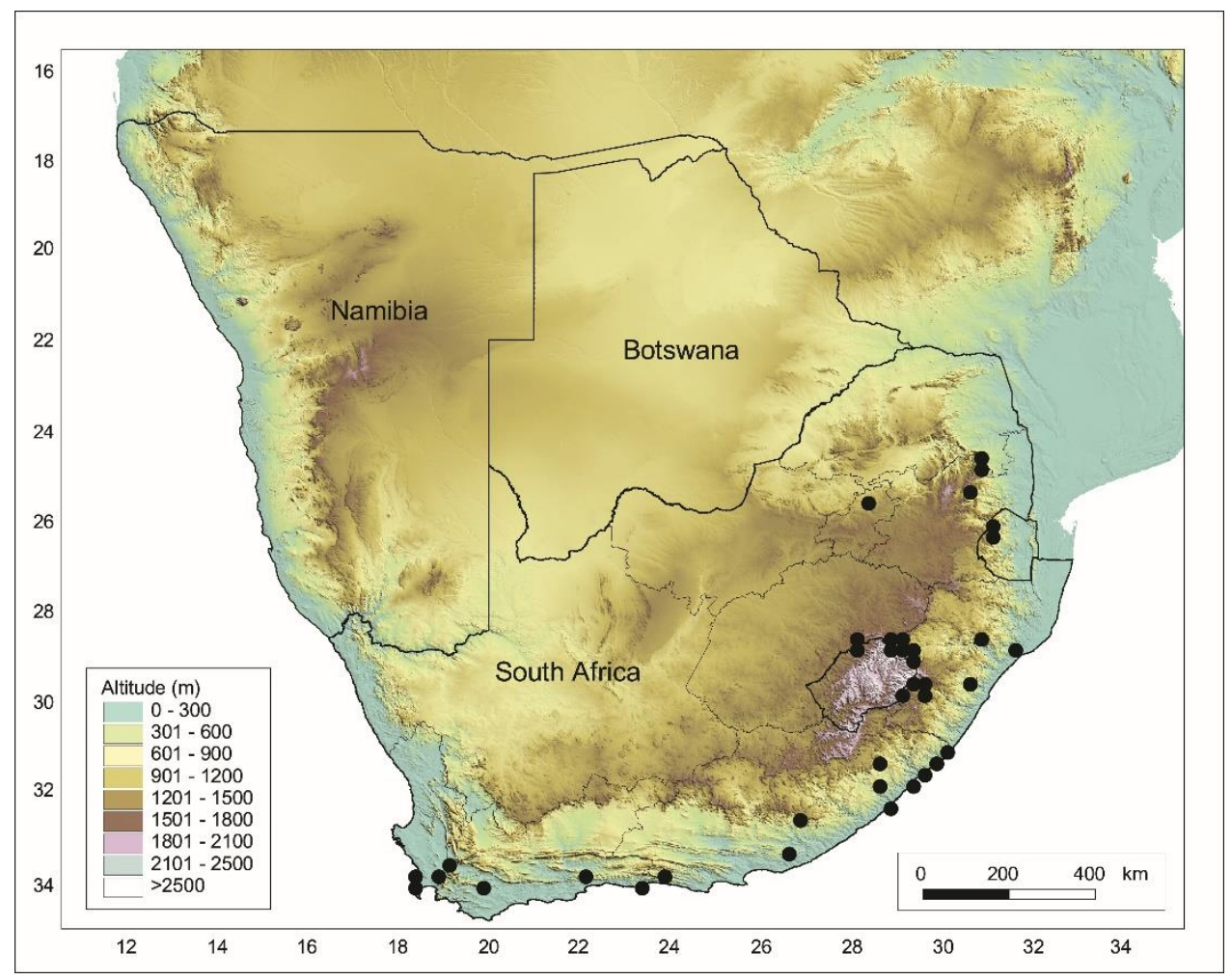

Fig 10: Distribution map for Sematophyllum subpinnatum (Brid.) E. Britton

Discussion: Usually easily recognized in the New World by its curved branches and homomallous leaves with bordered appearance, but in southern Africa it happens to be a highly variable species, and may actually contain more than one species filed under this name. Unfortunately for this study it was not possible to differentiate between groups and to address this question more deeply. Consequently we decided to recognize a wider concept of $S$. subpinnatum. Also the relationships with the new world specimens need to be investigated, but this is beyond the scope of this work.

Representative specimens examined: see Appendix.

Nomenclatural notes: Most (if not all) of the collections of this species in herbarium PRE were named Sematophyllum caespitosum Mitt. This name was widely (and mistakenly) used for this species for many years both in Africa and South America. Dixon (1920) and Buck (1983) have clarified the correct use of the name for this particular species. 


\subsection{Sematophyllum zuluense (Sim) Magill, Mem. Bot. Surv. S. Africa 43: 7. 1979.}

Rhaphidorrhynchium zuluense Sim., Trans. Roy. Soc. South Africa 15: 438. 1926. —TYPE: South Africa, Ngoya Forest, Zululand, 1000 feet, 1915, Sim 10285. (holotype: PRE!, isotype: BM!). Fig 12 F.

Plants medium sized, golden green. Stems creeping, freely branched, central strand absent. Pseudoparaphyllia absent. Stem and branch leaves similar, complanate, strongly lanceolate or linear-lanceolate, plane, 1.2-2.0 mm long, 0.20-0.35 mm wide; margins entire; apex acuminate; costae absent; laminal cells linear, smooth, 53-100 $\mu \mathrm{m}$ long, 5.0-7.5 $\mu \mathrm{m}$ wide, porose; alar cells enlarged, sometimes inflated, colored, consisting of 1 row. Asexual propagule absent. Autoicous. Perichaetial leaves erect, linear-lanceolate or ovate-lanceolate, plane, 1.5-1.8 mm long, 0.3-0.5 mm wide, apex acuminate to aristate, serrulate; costae absent, laminal cells linear to quadrate, smooth, 32-55 $\mu \mathrm{m}$ long, 7-9 $\mu \mathrm{m}$ wide, porose; alar cells differentiated, in $1 \mathrm{row}$, often colored. Setae elongate, smooth, ca $0.5 \mathrm{~cm}$ long; capsules inclined, ovate-oblong, ca. $0.5 \mathrm{~mm}$ long, constricted below mouth when dry; exothecial cells collenchymatous; annulus present, operculum long-rostrate; exostome furrowed, cross-striate below, coarsely papillose above, trabeculate at back; endostome with high basal membrane, keeled, perforated, cilia absent. Spores spherical, finely papillose, 13-20 $\mu \mathrm{m}$ across. Calyptrae not seen.

Distribution and habitat: Growing on tree bark or rocks from 300 to $1700 \mathrm{~m}$. Endemic to South Africa, S. zuluense is scattered throughout the Afromontane Region of Van Rooy \& Van Wyk (2010), as far north as Mariepskop in Mpumalanga. Fig. 11.

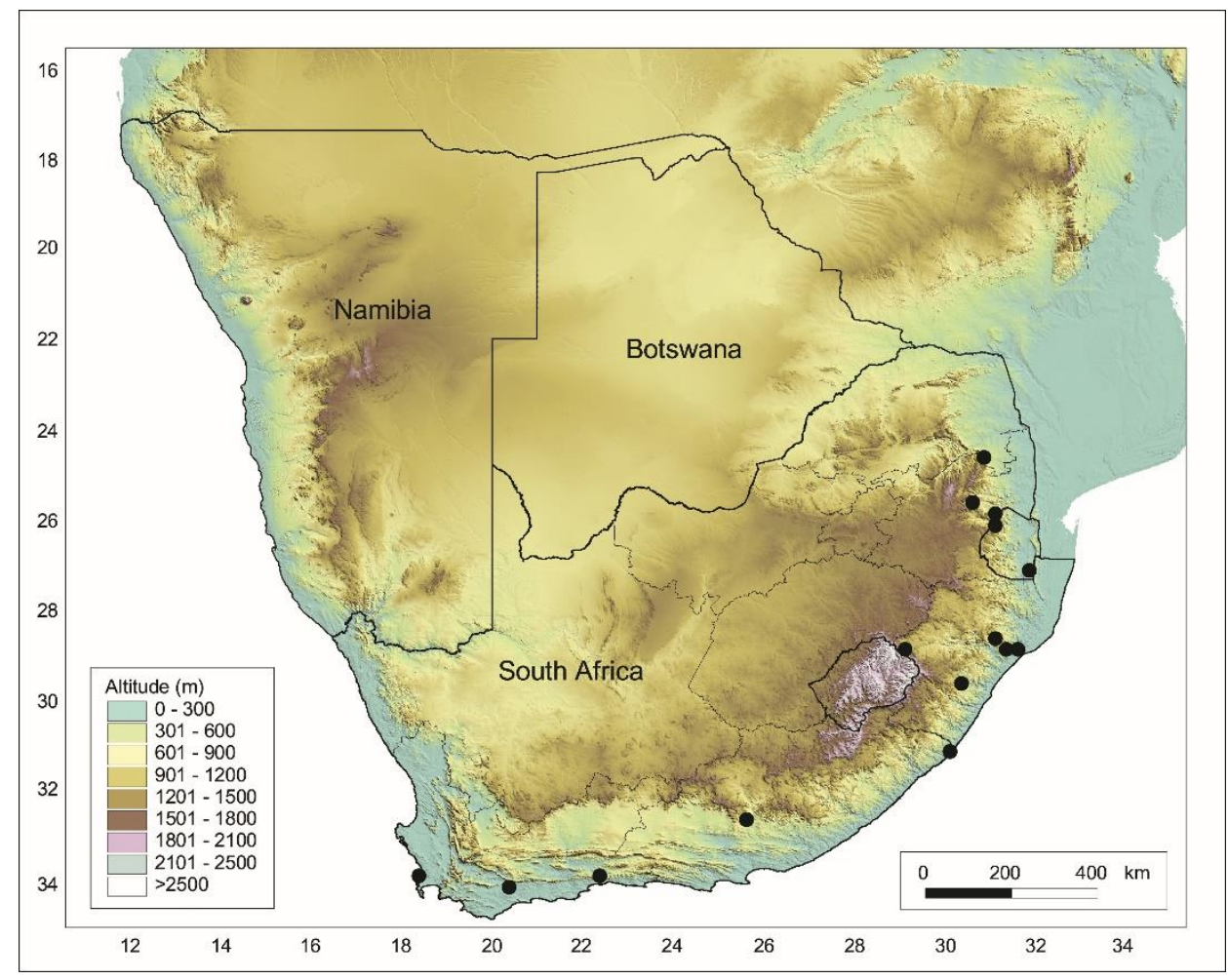

Fig 11: Distribution map for Sematophyllum zuluense (Sim) Magill

Discussion: This remarkable and somehow rare plant bears strong resemblance to representatives of Acroporium as well as the new world Aptychopsis and it is likely to be tranferred to either in the near future as molecular studies may reveal its true relationships. The furrowed exostome suggests its close relationship with Acroporium whereas its alar cells relate to both Acroporium and Aptychopsis.

In the original description (Sim 1926), the author has not seen the endostome and unfortunately the type specimens investigated only had one single capsule, but as other specimens were investigated by us, a more detailed description was possible and presented here.

Representative specimens examined: see Appendix. 


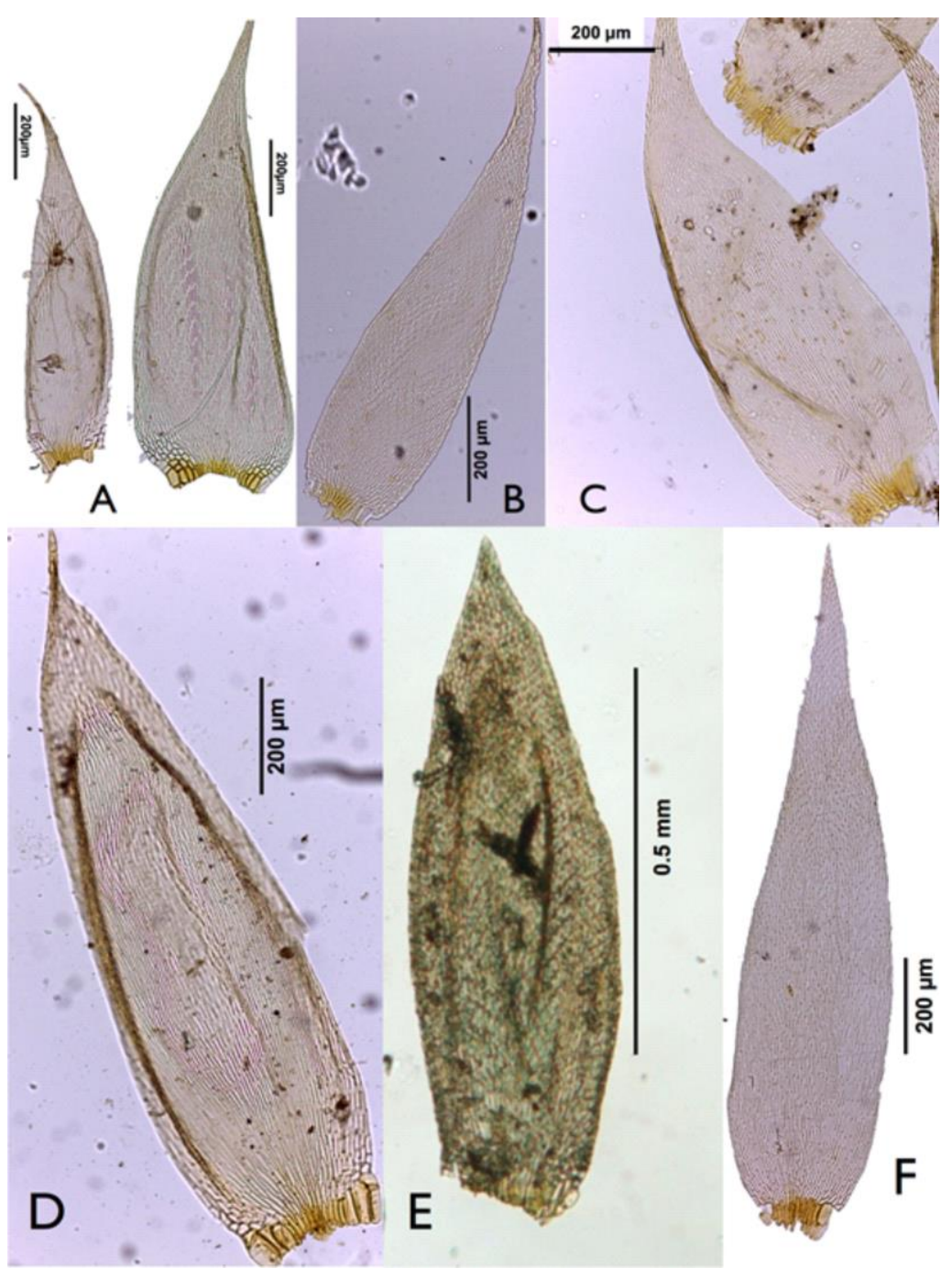

Fig 12: Leaves of A: Sematophyllum brachycarpum, B: S. dregei, C: S. gueinzii, D: S. sphaeropyxis, E: S. subpinnatum, F: S. zuluense. A from Pappe s.n. (holotype, BM), B from Drege [8048] (lectotype, BM), C from Pappe s.n. (holotype, BM), D from Rehmann 372 (BM), E from Rehmann 421 (PRE) and F from Sim 10285 (PRE).

\section{Trichosteleum Mitt., J. Linn. Soc., Bot. 10: 181. 1868.}

Trichosteleum perchlorosum Broth. \& Bryhn, Forh. Vidensk-Selsk Kristiania 1911(4): 24. 1911. -TYPE: [South Africa]. Zululand, Ekombe, in Sylva Ntingwe, Titlestad s.n. (C). Fig. 14.

Plants medium sized, golden green to yellow. Stems creeping, freely branched, central strand absent. Pseudoparaphyllia absent. Stem and branch leaves similar, incurved, lanceolate, falcate, 1.1-1.5 mm long, $0.28-0.33 \mathrm{~mm}$ wide; margins entire to denticulate above; apex acuminate to aristate; costae absent; laminal cells linear, smooth to papillose, 60-70 $\mu \mathrm{m}$ long, 4.5-6.0 $\mu \mathrm{m}$ wide; alar cells enlarged, inflated, colored. Asexual propagule absent. Autoicous. Perichaetial leaves erect, oblong-lanceolate, plane, 1.1-1.4 mm long, 0.3-0.4 mm wide, apex acuminate to aristate, serrulate; costae absent, laminal cells linear, smooth to papillose, 60-70 $\mu \mathrm{m}$ long, $7.0-8.5 \mu \mathrm{m}$ wide; alar cells poorly differentiated. Setae elongate, smooth, $0.5-0.7 \mathrm{~cm}$ long; capsules inclined to pendent, ovoid-cylindric, ca. $3 \mathrm{~mm}$ long, constricted below mouth when dry; exothecial cells collenchymatous; annulus present, operculum obliquely long-rostrate; exostome with zig-zag line, cross-striate below, coarsely papillose above, trabeculate at back; endostome with high basal membrane, keeled, cilia single, shorter than exostome teeth. Spores spherical, finely papillose, ca. $15 \mu \mathrm{m}$ across. Calyptrae cucullate, naked, smooth.

Distribution and habitat: Occurs as epiphytes and also on decaying logs or rock from sea level up to $3090 \mathrm{~m}$ high (Drakensberg). It is widespread throughout the Afromontane Region of Van Rooy and Van Wyk (2010), but unknown from the Gauteng Province. It was listed for Zimbabwe by O'Shea (2006), but we had not seen any voucher from there. Fig. 13. 
Discussion: This is the only papillae-bearing Sematophyllaceae in southern Africa. It is a very unique feature that helps to identify this species. However, it is not always easy to see its papillae under the light microscope, so it is important to look carefully, especially on leaves that are folded, which makes the papillae more visible. We have found leaves with and without papillae on the same plant. The falcate leaves also help to identify this species. This species closely resembles the New World Trichosteleum glaziovii (Hampe) W.R. Buck as they both share the papillose falcate leaves, however, the latter is of a much smaller size.

Representative species examined: see Appendix.

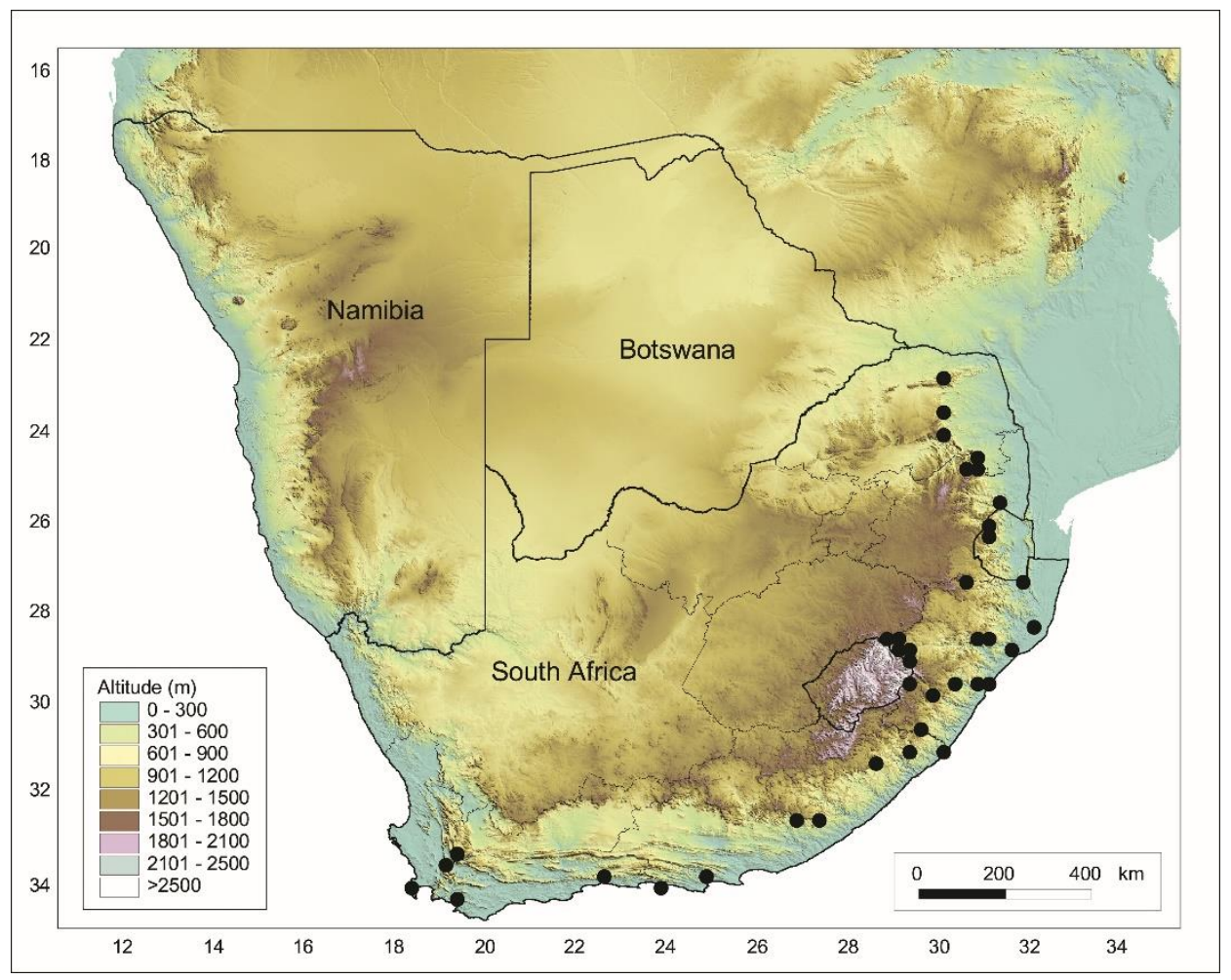

Fig 13: Distribution map for Trichosteleum perchlorosum Broth. \& Bryhn

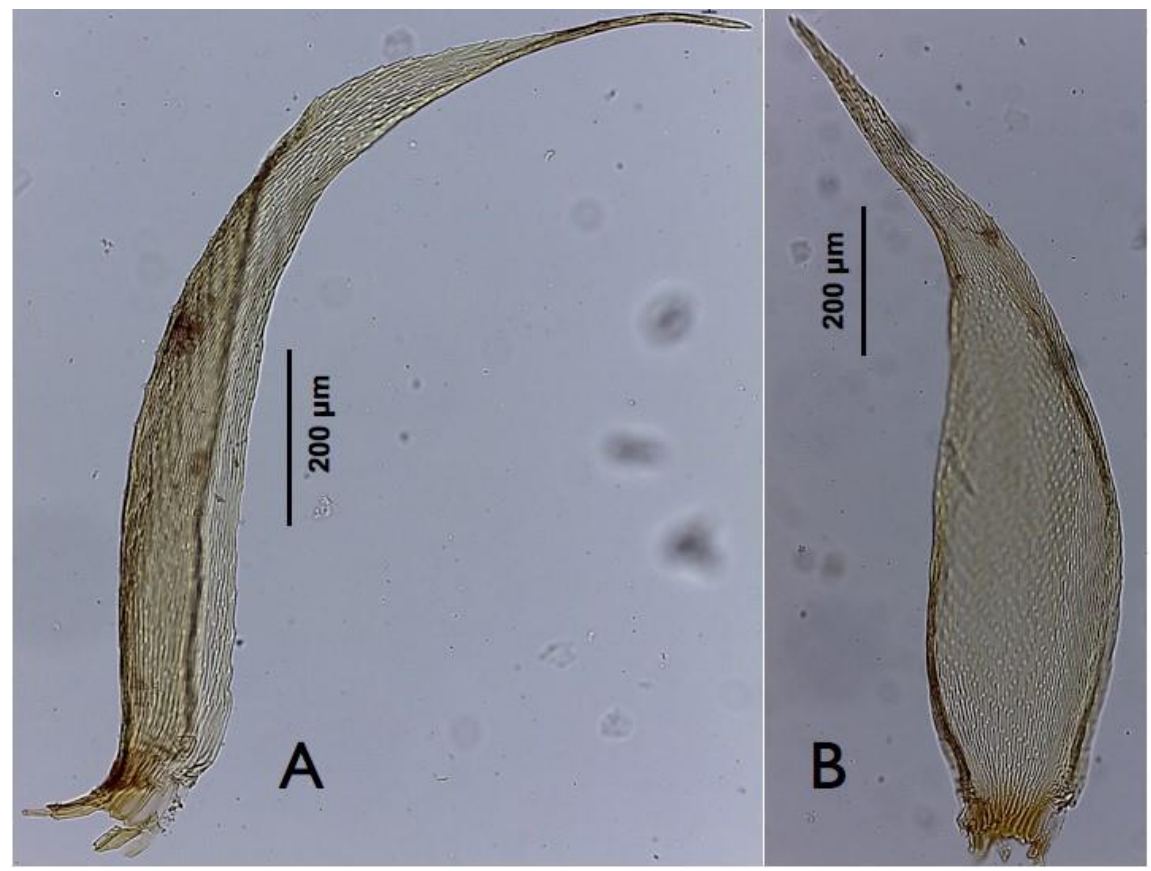

Fig 14: Leaves of Trichosteleum perchlorosum Broth. \& Bryhn. (A and B). From Titlestad s.n. (C). 
Acknowledgements: We are indebted to Hester Steyn for her help in preparing the distribution maps.

\section{References}

Brotherus V.F. (1908): Bryales, in part. I (3): 1057-1152. In: Engler H.G.A. \& Prantl K.A.E. (eds): Nat. Pflanzenfam., Engelmann, Leipzig.

Brummitt R.K. \& Powell C.E. (eds) (1992): Authors of Plant Names. A list of authors of scientific names of plants, with recommended standard form of their names including abbreviations. Royal Botanic Gardens, Kew, [4] $732 \mathrm{pp}$.

Buck W.R. (1983): Nomenclatural and taxonomic notes on West Indian Sematophyllaceae. - Brittonia 35: 309311.

Buck W.R. \& Tan B.C. (1989): The Asiatic genera of Sematophyllaceae associated with Trichosteleum. - Acta Bryol. Asiat. 1: 5-19.

Câmara P.E.A.S. \& Van Rooy J. (2014): A new species of Sematophyllum (Sematophyllaceae) from South Africa and a key to the southern African species of the genus. - The Bryologist 117 (3): 297-300.

Carvalho-Silva M., Stech M., Soares-Silva L.H., Buck W.R., Wickett N., Liu Y. \& Câmara P.E.A.S. (2017): A molecular phylogeny of the Sematophyllaceae s.l. (Hypnales) based on plastid, mitochondrial and nuclear markers, and its taxonomic implications. - Taxon 66(4): 811-831.

Dixon H. N. (1920): Rhaphidostegium caespitosum (Sw.) and its affinities. - J. Bot. 58: 81-89.

Frey W. \& Stech M. (2009): Bryophytes and seedless vascular plants 3: I-IX. In: Syl. Pl. Fam. ed. 13. Gebr. Borntraeger Verlagsbuchhandlung, Berlin, Stuttgart.

Goffinet B. \& Buck W.R. (2004): Systematics of the Bryophyta (mosses): from molecules to a revised classification, 205-239 pp. In: Goffinet B., Hollowell V. \& Magill R.E. (eds): Molecular systematics of bryophytes. - Monogr. Syst. Bot. Missouri Bot. Gard vol. 98, Missouri Botanical Garden, St. Louis.

Goffinet B., Buck W.R. \& Shaw A.J. (2009): Morphology, anatomy, and classification of the Bryophyta, 55138 pp. In: Bryoph. Biol. Ed. 2. Cambridge University Press, Cambridge, U.K.

Grad stein S.R., Churchill S.P. \& Salazar Allen N. (2001): Guide to the bryophytes of tropical America. - Mem. New York Bot. Gard. 86, 577 pp.

Lawrence G.M.H., Buchheim A.F.G., Daniels G.S. \& Dolezal H. (1968): B-P-H; Botanico-PeriodicumHuntianum. Hunt Botanical Library, Pittsburgh, Penn., 1063 pp.

Magill R.E. (1990): Glossarium polyglottum bryologiae: a multilingual glossary for bryology. - Monogr. Syst. Bot. Missouri Bot. Gard. 33, 297 pp.

Magill R.E. \& Schelpe E.A. (1979): The bryophytes of southern Africa: an annotated checklist. - Mem. Bot. Surv. S. Africa 43, $38 \mathrm{pp}$.

Mitten W. (1869): Musci Austro-Americani. - J. Linn. Soc., Bot. 12, 659 pp.

O'Shea B.J. (2006): Checklist of the mosses of sub-Saharan Africa. - Trop. Bryol. Res. Rep. 6: 1-252.

Sim T.R. (1926): The Bryophyta of South Africa. - Trans. Roy. Soc. South Africa 15, 475 pp.

Tan B.C. \& Jia Y. (1999): A preliminary revision of Chinese Sematophyllaceae. - J. Hattori Bot. Lab. 86: 1-70.

Tsubota H., Akiyama H., Yamaguchi T., \& Deguchi H. (2001a): Molecular phylogeny of the Sematophyllaceae (Hypnales, Musci) based on chloroplast rbcL sequences. - J. Hattori Bot. Lab. 90: 221-240.

Tsubota H., Akiyama H., Yamaguchi T. \& Deguchi, H. (2001b): Molecular phylogeny of the genus Trismegistia and related genera (Sematophyllaceae, Musci) based on chloroplast rbc L sequences. - Hikobia 13: 529-549.

Van Rooy J. (1993): Musci, 17-46 pp. In: Arnold T.H. \& De Wet B.C. (eds): Plants of southern Africa: names and distribution. - Mem. Bot. Surv. S. Afr. 62. National Botanical Institute, Pretoria.

- (2003): Bryophyta, 2-37 pp. In: Germishuysen G. \& Meyer N.L. (eds): Plants of southern Africa: an annotated checklist. - Strelitzia 14. National Botanical Institute, Pretoria.

- (2006): Bryophyta, 1-30 pp. In: Germishuysen G., Meyer N.L., Steenkamp Y. \& Keith M. (eds): A checklist of South African plants. - Southern African Botanical Diversity Network Report 41. SABONET, Pretoria.

Van Rooy J. \& Van Wyk A.E. (2010): The bryofloristic regions of southern Africa. J. Bryol. 32: 80-91.

- (2011): The bryofloristic elements of southern Africa. J. Bryol. 33: 17-29.

Authors' addresses: Paulo Câmara, Universidade de Brasilia, Depto de Botânica, Campus Darcy Ribeiro, Asa Norte, Brasilia, DF - Brazil and Missouri Botanical Garden, PO Box 299, Saint Louis, MO, USA.

Jacques van Rooy, National Herbarium, South African National Biodiversity Institute (SANBI), Private Bag X101, Pretoria 0001, South Africa and School of Animal, Plant and Environmental Sciences, University of the Witwatersrand, Private Bag 3, Wits 2050, Johannesburg, South Africa.

Micheline Carvalho-Silva, Universidade Federal dos Vales do Jequitinhonha e Mucuri, Unaí, Brasil.

Robert Magill, Missouri Botanical Garden, PO Box 299, Saint Louis, MO, USA. 


\section{APPENDIX: REPRESENTATIVE SPECIMENS EXAMINED.}

Donnellia fuscescens- Free State: Meiringspoort Nature Park, Van Rooy 336, 338 (PRE). Gauteng: Donkerpoort, Doidge \& Bottomley s.n. (PRE); Hartebeeshoek Satellite tracking station, Van Rooy 3984 (PRE). KwaZulu-Natal: Goodoo pass, Bews sub Sim 8396 (PRE); Sani Pass area, Magill 7039, 7258, 7292, 7314 (MO); Cathedral Peak area, Magill 6867, 6894 (MO); between Eston and Richmond, Van Rooy 1026 (PRE); Inanda, Rehmann 422 (PRE); Knoll, Hilton road, Sim CH7961 (PRE); Royal Natal National Park, Crosby \& Crosby 7831 (PRE, MO); Van Reenen, Wager 195, 551, 7741 B (PRE). Limpopo: Entabeni Sate Forest, Glen 3918 (PRE); Mpumalanga: Mount Sheba Nature Reserve, Knox 12 (PRE); Rooiwal, Bosman CH6384 (PRE); Waterval-Boven, Van Rooy \& Perold 3824 (PRE). Western Cape: George, Perold 926 (PRE); Knysna, Russel 2573 (PRE); Table Mountain, Pillans 3988 (PRE), Sim 9158 (PRE). Swaziland: Malolotja Nature Reserve, Braun 719 (PRE).

Sematophyllum brachycarpum - Eastern Cape: Butterworth area, Manubi Forest, Linder 1227 (PRE); Bizana, Ndunge forest, Phephu 36 (PRE); Grahamstown, Jacot-Guillarmod 7806 (PRE); Hluleka Nature Reserve, Hoffman 32 (PRE); Hogsback, Jacot-Guillarmod CH12578 (PRE); Kwelera River near East London, Van Rooy 935 (PRE); Magwa Falls, Van Rooy 1899 (PRE); Mlengana, Van Rooy 2014 (PRE); Mkambati Game Reserve, Abbott 7188 (PRE); Ntabankulu, KuGomo forest, Phephu 66 (PRE); Port St Johns, Wager 1450 (PRE); Transkei, Ka-Imsizizi, Stirton 5702 (PRE); Uitenhage, Smook 3823 (PRE). Free State: Ladybrand, Van Rooy 564 (PRE). Gauteng: Hartebeeshoek Satellite Tracking Station, Van Rooy 4001 (PRE); Pretoria, Bosman 1162A (PRE). KwaZulu-Natal: NE of Vryheid, Magill 5063 (PRE); between Kranskop and Vryheid, Magill 5096 (PRE); Bushmans Nek, Van Rooy 1496 (PRE); Capuchin Convent, Van Rooy 981 (PRE); Donnybrook, Scott CH11224 (PRE); Cathedral Peak Forest Station, Van Rooy 1195 (PRE); Cathedral Peak area, Magill 6826, 6862, 6901, 6972, 6974, 6986, 6990, 6994, 7010, 7021, 7029 (MO); Cobham Forest Station, Magill 7341, 7343, 7351, 7354, 7358, 7368, 7373, 7386 (MO); Giants Castle, Retief 1674 (PRE); Royal Natal National Park, Magill 6718 (MO); Sani Pass, Magill 7251, 7252 (MO); Sani Pass Hotel, Van Rooy 1443 (PRE); Richards Bay, Magill 5331 (PRE); Durban, Palmiet Nature Reserve, Lambert 9 (PRE); Eastern Shores Nature Reserve, Van Rooy 194 (PRE); Enseleni Nature Reserve, s.l. s.n, (PRE); Eshowe, Signal Hill, Van der Plank 151 (PRE); Everton, Stirton 5506 (PRE); 19 km from Greytown to Pietermaritzburg, Stirton 5292 (PRE); Harding, Stirton 5687 (PRE); Hlabisa District, Mahlonza, Taylor 468 (PRE); Hilton Road, Sim 8983 (PRE); Imbezane, Eyles 1424 (PRE); Inanda, Perold 21 (PRE); Ingwavuma, Smook 5745 (PRE); Kosi Bay, Vahrmeijer 12930 (PRE); Lebombo Mountains, Magill 5466 (PRE); Cathkin, Owen 52 (PRE); Makakatini Flats, Magill 5435 (PRE); Merrivale, Sim CH8051 (PRE); Midmar Dam, Taylor 444 (PRE); Mtubatuba, Glen 2725 (PRE); Mtunzini, Smook 1520 (PRE); Ngome Forest Reserve, Oliver $7057 A$ (PRE); Oliviershoek Pass, Magill 6800 (MO); Pietermaritzburg, Magill 7469, 7481 (MO); Pietermaritzburg, Wells 64, (PRE); Port Shepstone, Ellis M11 (PRE); Ramsgate, Van Rooy 969 (PRE); Richards Bay, Van Rooy 182 (PRE); Nelspruit, Rooiwal, Bosman CH6398 (PRE); Rosetta Farm, Sim CH8864 (PRE); Rydal Mount, Wager 542 (PRE); St. Lucia, Wager 55 (PRE); Tugela Gorge, Cholnoky 109 (PRE, S); Umgoye Forest Reserve, Magill 5276 (PRE); Van Reenen, Wager 1079c (PRE). Limpopo: New Agatha Forest Reserve, Von Breitenbach 117 (PRE); Jan Trichardt Pass, Van Rooy 3894 (PRE); Kruger National Park, Punda Milia, Magill 5020 (PRE); Westfalia Estate, Scheepers 1223 (PRE); Mariepskop, Vorster 293 (PRE); Mount Lejuma, Magill 3660 (PRE); Mutale, North of Gundani village, Koekemoer 2258 (PRE); Nylstroom, Vahrmeijer 12937 (PRE); Houtbosdorp, Van Vuuren 1479 (PRE); Sekhukhuneland, Luluberg, Magill 3354 (PRE); Mount Lejuma, Magill 3669 (PRE); Woodbush, Brenan M2788 (PRE); Waterberg, Smook 2533b (PRE); Zebediela, Magill 3825 (PRE); Zoutpansberg, Piesanghoek, Bosman CH1417 (PRE). Mpumalanga: Mac Mac Falls, Rankin 100 (PRE); Belfast, Stirton 6719 (PRE); Blyde River Canyon, Brenan M3372 (PRE); Buffelskloof Nature Reserve, Van Rooy 4173 (PRE); Carolina, Van Hoepen 1775, 1777 (PRE); East of Barberton, Oliver 7157 (PRE); Pilgrim's Rest, Magill 4856 (PRE); Josefsdal, Phephu 176 (PRE); Buffelskloof Nature reserve, Glen 3312 (PRE); Loskopdam, Oliver 7370 (PRE); Manywana River crossing to Sodwana Bay, Magill 5387 (PRE); Morgenzon Forest Reserve, Crosby \& Crosby 7757 (PRE, MO); between Sabie and Graskop, Cholnoky 507 (PRE); Wakkerstroom, Perold 704 (PRE); $30 \mathrm{~km}$ SE of Carolina, Magill 3398 (PRE); Waterval-Boven, Van Rooy \& Perold 3786 (PRE). North West: Kromrivier near Buffelspoort, Bottomley \& Doidge CH10946 (PRE); Magaliesberg, Baviaanskrans, Magill 3121 (PRE); Western Cape: Constantia Kloof, Sim 9337 (PRE); Cape Town, Wynberg, Garside 6486 (PRE); Claremont, Arts RSA03/05 (PRE); Devils Peak, Sim 9232 (PRE); George, Wager CH11568 (PRE); Knysna, Lewis CH12217 (PRE); Kirstenbosch, Magill 4100 (PRE); Koloniesbos, Magill 6184 (PRE); between Oudtshoorn and George, Magill 6082 (PRE); Rondebosch, Rehmann 420 (PRE); Rosebank, Bottomley CH1376 (PRE); Stellenbosch, Duthie CH11023 (PRE); Strandskloof, Magill 6265 (PRE); Table Mountain, Arts RSA08/21 (PRE); Tulbagh, Groot Winterhoek, Esterhuysen 19869 (PRE). Swaziland: Droxford Farm S of Ngwenya Border Post, Magill 3439 (PRE); Forbes Reef, Magill 3530 (PRE); Jilobi Forest, Kemp 1340 (PRE); Lubombo District, Blue Jay Ranch, Magill 3602 (PRE); Mbabane, Kemp 748 (PRE); Luyengo, Kemp 776 (PRE).

Sematophyllum dregei- Eastern Cape: Grahamstown, Farquhar 64 (PRE); Hogsback, Oliver 6789 (PRE); Hluleka Nature Reserve, Hoffman 24 (PRE); Mlanlane Forest Station, Van Rooy 2217 (PRE); Mkambati Nature 
Reserve, Van Rooy 1735 (PRE), Pondoland, Sim 8061 (PRE). KwaZulu-Natal: Cathkin Park Hotel, Filter 15 (PRE); Champagne Castle, Cholnoky 353 (PRE, S); Dhlinza Forest Reserve, Crosby 7779 (PRE, MO); Cathedral Peak, Van Rooy 1239 (PRE); Cathedral Peak, Magill 6819, 6859, 6957, 7005, 7013, 7018 (MO); Sani Pass, Magill 7181, 7194, 7256 (MO); Ingeli Forest, Smook 1760 (PRE); Knoll, Hilton Road, Sim CH7989 (PRE); between Kranskop and Vryheid, Van Rooy 69 (PRE); Rosetta Farm, Sim CH7974 (PRE); Loteni Nature Reserve, Phelan 352 (PRE); Mooi River, Sim CH7965 (PRE); Ndedema Forest, Van Rooy 1576 (PRE); Ngome Forest Reserve, Oliver 7097 (PRE); Tugela valley, Doidge CH723 (PRE); Nkandla Forest Reserve, Magill 5212 (PRE); Oribi Gorge, Oliver 7347 (PRE); Qudeni Forest, Magill 5126 (PRE); Qudeni Forest Reserve, Van Rooy 83 (PRE); Pietermaritzburg, Wood 49 (PRE); Xumeni Forest, Doidge 31 (PRE). Limpopo: Entabeni, Wager 287 (PRE); Mariepskop, Vorster 1564 (PRE, MO); Wolkberg, Serala Mountain, von Breitenbach 133 (PRE); Soutpansberg, Louis Trichardt, Smook \& Phelan 670 (PRE); New Agatha Forest Rererve, von Beitenbach 91 (PRE); Waterberg, Smook 2513 (PRE); Wolkberg, Serala Peak, Venter 11396 (PRE); Woodbush Forest Reserve, Crosby 7533 (PRE, MO). Mpumalanga: Berlin Forest Reserve, von Brietenbach 277, 443 (PRE); God's Window, Brenan 3377 (PRE); Morgenzon Forest Reserve, Crosby 7762 (PRE, MO); Tweefontein Forest, Cholnoky 517, 639 (PRE, S). Western Cape: Cederberg, Barnard 48198 (PRE); Constantia kloof, Sim 9339 (PRE); Du Toits Kloof, Esterhuysen 15657 (PRE); George, Wager 293 (PRE); Hottentots-Holland, Sieben 39 (PRE); Kliphuis River near Clanwilliam, Magill \& Schelpe 4050 (PRE); Knysna, Deepwalls, Bottomley CH11000 (PRE); Oudebos, Zonder Einde, Thorne 50497 (PRE); Montagu Pass, Rehmann 409 (PRE); Wemmershoek valley, Esterhuysen 24361 (PRE); Saasveld College, Arts RSA17/07 (PRE); Slanghoek Mountains, Esterhuysen 22271 (PRE); Steenbras, Thorne 50477 (PRE); Jonkershoek valley, Stephens 111 (PRE); Swellendam State Forest, Perold 2561 (PRE); Table Mountain, Esterhuysen 17550 (PRE); Tsitsikama Forest, Arts 19/13 (PRE); Winterhoek Mountains, Sneeugat Valley, Barnard 50336 (PRE); Kromrivier Kloof, Esterhuysen 25386 (PRE). Swaziland: Forbes Reef, Magill 3541 (PRE); Mbabane, Kemp 1054 (PRE); Phophonyane falls, Perold \& Koekmoer 3157 (PRE).

Sematophyllum gueinzii-Eastern Cape: Dwesa Nature Reserve, Van Rooy 2105 (PRE); Hogsback, Arts RSA21/28 (PRE); Tsitsikamma Forest National Park, Retief $407 a$ (PRE); Ntabankulu, Phephu, 120 (PRE, MO); Mkambati Nature Reserve, Van Rooy 1773 (PRE); Magwa falls, Russell 2658 (PRE); Silaka Nature Reserve, Van Rooy 1921 a (PRE); Hluleka Nature Reserve, Van Rooy 2186 (PRE). Gauteng: Pretoria, Mogg CH1330 (PRE). KwaZulu-Natal: Cathedral Peak area, Magill 6953 (MO); Indumeni Forest, Magill 5611, Van Rooy 1647 (PRE); Weza Forest Reserve, Van Breitenbach 396 (PRE); Nkandla Forest Reserve, Magill 5213 (PRE); Pietermaritzburg, Van Rooy 1530 (PRE); Royal Natal National Park, Crosby 7841 (PRE, MO); Van Reenen, Wager CH11547 (PRE); between Vryheid and Kranskop, Magill 5088 (PRE). Limpopo: Entabeni Forest, von Breitenbach 468 (PRE); Mariepskop, Crosby 7626 (PRE, MO). Mpumalanga: Berlin Forest Reserve, von Breitenbach 454 (PRE); Ngodwana, Van Rooy 4060 (PRE); Buffelskloof Nature Reserve, Van Rooy 4087 (PRE). Western Cape: Bishopscourt, Sim 9458 (PRE); Cape Town, Devil's Peak, Sim 9245 (PRE); Diepwalle Forest, Arts RSA26/05 (PRE); George, Geelhoutboomberg, Geldenhuys 481 (PRE); George, Wager 786 (PRE); Groenkop Forest Reserve, Crosby 8083 (PRE, MO); Helderberg, Lourensford, Pillans CH13531 (PRE); Villiersdorp, Sneeukop, Perold 626 (PRE); Kirstenbosch, Esterhuysen 25641 (PRE); Knysna, Wager 784 (PRE); Montagu Pass, Rehmann 659 (PRE); Newlands Ravine, Sim 9415 (PRE); Oudebos, Zonder Einde, Thorne CH3609 (PRE); Palmiet River Mountains, Barnard 41677 (PRE); Steenbras, Spitskop, Thorne 50478 (PRE); Swartberg Pass, Stokoe CH13530 (PRE); Swellendam, Marloth Nature Reserve, Schelpe 7661 (PRE); Table Mountain, Sim 9129 (PRE); Tsitsikamma Forest, Arts RSA19/14 (PRE); Wellington, Seven Sisters mountains, Barnard CH3100, 49642 (PRE); Tulbagh, Sneeugat valley, Thorne 50361 (PRE). Swaziland: Mount Kelley, Magill 3423 (PRE).

Sematophyllum magillianum - Eastern Cape: Dwessa Forest, Van Rooy 2093 (PRE, MO); Hogsback, Seagrief CH13965 (PRE); Ngabara River crossing, 10 km from Dwesa, Van Rooy 2075 (PRE); Silaka Nature Reserve, Van Rooy 1931 (PRE); Port St Johns, Russell 2678 (PRE). KwaZulu-Natal: Ahrens, Lilani Valley, Oliver 6754 (PRE); Cathedral Peak area, Magill 6868, 6884, 6911 (MO); Eshowe, Signal Hill, Van der Plank 229 (PRE); Imbezane, Eyles 1401 (PRE); Inanda, Rhemann 342 (PRE); Knoll, Hilton road, Sim CH8026 (PRE); Ngoya Forest, Sim 10338 (PRE); Orbi Gorge, Umzimkulu River, Cholnoky 158 (PRE); Sandlundlu River, Begg Hl3135 (PRE). Limpopo: Mount Lejuma, Magill 3687 (PRE). Mpumalanga: Type. Western Cape: Blinkwater Ravine above Camps Bay, Bews sub Sim 8616 (PRE); Table Mountain, Sim 9403 (PRE). North West: Magaliesberg, Tonquani Ravine, Crosby \& Crosby 7480 (PRE).

Sematophyllum sphaeropyxis — Eastern Cape: Butterworth, Manubi Forest, Linder 1235 (PRE); Hluleka Nature Reserve, Van Rooy 2194 (PRE); Elliotdale, Van Rooy 2135 (PRE); Hankey, Sim CH8009 (PRE); Hogsback, Arts RSA22/13 (PRE); Idutywa, Van Rooy 2021 (PRE); Mkambati Nature Reserve, Van Rooy 1790 (PRE); Mlanlane Forest Station, Van Rooy 2243, 2325 (PRE); Nelspruit district, Rooiwal, Bosman CH6385 (PRE); Ngabara River crossing from Dwesa, Van Rooy 2062 (PRE); Port St. John's, Russell 2645 b (PRE); Port Alfred, Horseshoe bend, Kowie River, Bosman CH1562 (PRE). Free State: Zastron, Van Rooy 2502 (PRE). Gauteng: Boekenhoutskloof, Mogg CH3345 (PRE); Ezemvelo Nature Reserve, Van Rooy 3945 (PRE); Johannesburg, Edwards CH8070 (PRE); Pretoria, Waterkloof, Mogg CH1145 (PRE). KwaZulu-Natal: Cobham Forest Reserve, Van Rooy 1393 (PRE); 
lower Sani Pass, Magill 7182 (MO); Cathedral Peak Forest Station, Magill 5720 (PRE); Sani Pass Hotel, Perold 2510 (PRE); Eastern Shores Nature Reserve, Van Rooy 197 (PRE); Eshowe, Van der Plank 5412 (PRE); Glenside, Sim CH8054 (PRE); Hlabisa, Harrison 6 (PRE); Inanda, Rehmann 662 (PRE); Ixopo, Arnold 1357 (PRE); KuNkanini stream crossing on Kosi Bay road, Magill 5428 (PRE); Lebombo Mountains near Jozini, Van Rooy 259 (PRE); Makhathini flats, Magill 5432 (PRE); Margate, Van Rooy 976 (PRE); Merrivale, Sim CH8056 (PRE); Lake St Lucia Eastern shores, Taylor 453 (PRE); Mtunzini, Smook 1529 (PRE); Ndedema Forest, Van Rooy 1545 (PRE); Nels Rust, Sim CH8256 (PRE); Port Shepstone, Sim CH7955 (PRE); Royal Natal National Park, Smook 1464 (PRE); Rydal Mount, Wager 1205c (PRE); Sodwana Bay, Magill 5399, Van Rooy 219 (PRE); Sihangwane on Ingwavuma-Maputa road, Van Rooy 245 (PRE); St. Lucia Game Reserve, Glen 2719 (PRE); Umgoye Forest Reserve, Van Rooy 147 (PRE); between Vryheid and Kranskop, Van Rooy 64 (PRE). Limpopo: De Hoek Forest Station, von Breitenbach 186 (PRE); Haenertsburg, Brenan 3369 (PRE); Jan Trichardt Pass, Van Rooy 3890 (PRE); Hangklip Forest Reserve, Smook \& Phelan 668 (PRE); Kruger National Park, Punda Milia, Magill 4974 (PRE); Westfalia Estate, Van Vuuren 1520 (PRE); Marakele National Park, Van Rooyen 4460 (PRE); Messina, Entabeni road, von Breitenbach 193 (PRE); Mutale District, valley north of Gundani village Koekemoer 2255 (PRE); New Agatha Forest Reserve, von Breitenbach 128 (PRE); Spelonken, Junod 9 (PRE); Mount Lejuma, Magill 3674 (PRE); De Hoek Forest Reserve, Debengeni Falls, Schelpe CH13529 (PRE); Piesanghoek, Bosman CH1351 (PRE). Mpumalanga: Belfast, Bottomley CH2994 (PRE); Buffelskloof Nature Reserve, Van Rooy 4179 (PRE); Bushmans Rock, Stirton 9913 (PRE); near Marmerkop Station between Dullstroom and Lydenburg, Perold 423 (PRE); Lochiel, Smook 4973 (PRE); Lothair, Gunn CH11196 (PRE); Loskop Dam, Kanongat, Oliver 7372a (PRE); Middelburg, Farm Bankfontein, Magill 6378, Perold 72 (PRE); Nelshoogte Pass, Magill 4731 (PRE); along SabieNelspruit road, Magill 4806 (PRE); Waterval-Boven, Van Rooy \& Perold 3826 (PRE); Kaapmuiden, Magill 4767 (PRE); Rietfontein, Wager 724 (PRE). North West: Magaliesberg, Tiger Kloof, Magill 3079 (PRE). Western Cape: Claremont, Duncan PRE56985 (PRE); Kenilworth, Duncan CH7954 (PRE); Knysna, Duthie CH7979 (PRE); Strandskloof, Magill 6272 (PRE). Swaziland: Forbes Reef, Magill 3491 (PRE); Jilobi Forest, Kemp 1482 (PRE); Mlawula Ranch north of Siteki, Magill 3557 (PRE); Malkerns Research Station, Kemp 1341 (PRE); Malolotja Nature Reserve Braun 704 (PRE); 28 km SE of Siteki, Kemp 806 (PRE). Lesotho: Maloti Mountains, Moteng Pass west, Van Rooy 3101 (PRE).

Sematophyllum subpinnatum - Eastern Cape: Grahamstown, Farquhar 6 (PRE); Hogsback, Arts RSA21/01 (PRE); Hluleka Nature Reserve, Van Rooy 2197 (PRE); Mlanlane Forest Station, Van Rooy 2254, 2313 (PRE); Mkambati Nature Reserve, Van Rooy 1729, 1734 (PRE); Ngabara River crossing from Dwesa, Van Rooy 2044 (PRE); Port St Johns, Wager CH1427 (PRE); along road from Elliotdale to The Haven, Van Rooy 2147 (PRE); Storms River Gorge, Schelpe 7834 (PRE). Free State: Kadziberg, Rehmann 371 (PRE); Meiringspoort, Van Rooy 343 (PRE). Gauteng: Pretoria National Botanical Garden, Van Rooy $4047 a$ (PRE). KwaZulu-Natal: Cathedral Peak area, Schelpe 7573 (PRE); Cathkin Peak Forest Reserve, Crosby 7913 (PRE, MO); Drakensberg, Cholnoky 113 (PRE, S); Cathedral Peak, Schelpe 7527 (PRE); Cathedral Peak, Magill 6866, 6910 (MO); Indumeni Forest, Van Rooy 1633 (PRE); Cobham Forest Station, Magill 7316 (MO); Royal Natal National Park, Magill 6713 (MO); lower Sani Pass, Magill 7038, 7261 (MO); Inanda, Rehmann 663 (PRE); Himeville, Perold \& Koekmoer 4319 (PRE); Ndedema Forest, Van Rooy 1566, 1588 (PRE); Oliviershoek, Schelpe 7943 (PRE); Qudeni Forest, Edwards 1511, Magill 5135 (PRE); Polela, Sim CH8089 (PRE); Port Edward, Van Rooy 964 (PRE); Umgoye Forest Reserve, Van Rooy 152 (PRE); Injasuti kloof, Esterhuysen 20217B (PRE). Limpopo: Mariepskop, Scott (PRE). Mpumalanga: Buffelskloof Nature Reserve, Van Rooy 4199 (PRE); Mount Sheba Nature Reserve, Knox 19 (PRE). Western Cape: Blinkwater Ravine above Camps Bay, Bews sub Sim 8589 (PRE); Kirstenbosch Botanical gardens, Arts RSA03/48 (PRE); Constantia, Perold 658 (PRE); Devils Peak, Rehmann 421 (PRE); Du Toits Kloof, Thorne 51125 (PRE); Kloof Nek, Bottomley CH1368 (PRE); Keurbooms River, Barnard 49179 (PRE); Newlands ravine, Sim 9450 (PRE); Oudebosch, Thorne CH6432 (PRE); Robinson Pass, Thorne 49756 (PRE); Stellenbosch, Banhoek valley, Thorne CH6450 (PRE); Table Mountain, Thorne CH6440 (PRE). Swaziland: Mt. Kelley, Magill 3426 (PRE); on road to Piggs Peak from Forbes Reef, Magill 3468 (PRE).

Sematophyllum zuluense - Eastern Cape: Boschberg, Sim CH7874 (PRE); Mkambati Nature Reserve, Smook 6157, Van Rooy 1732 (PRE). KwaZulu-Natal: Dhlinza Forest, Smook 1366 (PRE); Cathedral Peak Research Area, Van Rooy 1242 (PRE); Lebombo Moutains S of Ingwavuma, Van Rooy 282 (PRE); Ngoye Forest, Sim 10334 (PRE); Nkandla Forest Reserve, Magill 5236 (PRE); Pietermaritzburg, Wells 61 (PRE); Umgoye Forest Reserve, Magill 5282 (PRE). Mpumalanga: Mariepskop plantation, Crosby 7610 (PRE, MO); Berlin Forest Reserve, von Breitenbach 283 (PRE); Saddleback Pass, Perold \& Koekomoer 3141 (PRE). Western Cape: Camps Bay, Garside M63 (PRE); George, Wager 1499 (PRE); Swellendam, State Forest, Perold 2561 (PRE). Swaziland: Forbes Reef, Glen 3128 (PRE).

Trichosteleum perchlorosum - Eastern Cape: Hankey, Sim CH1113 (PRE); Hogsback, Oliver 6796(PRE); Mkambati Nature Reserve, Smook 6161 (PRE); Mlanlane Forest Station, Van Rooy 2295 (PRE); Ntabankulu, KuGomo Forest, Phephu 76 (PRE); Pirie Forest, Sim 10294 (PRE). KwaZulu-Natal: Indumeni Forest, Van Rooy 1616 (PRE); Cathedral Peak, Magill 6890 (MO); lower Sani Pass, Magill 7266 (MO); Cathkin Park Hotel, Filter 
25 (PRE); Inanda, Hood sub Sim 10290 (PRE); Inanda Game Park, Perold 17 (PRE); Knoll, Hilton Road, Sim CH7961 (PRE); Lebombo Mountains, N'dabeni Forest Van Rooy 277 (PRE); Little Switzerland, Brenan M3013 (PRE); Mtubatuba, Taylor 454 (PRE); Nkandla Forest Reserve, Magill 5240 (MO); Ndedema Forest, Van Rooy 1605 (PRE); Pongola Bush Nature Reserve, Glen 2428 (PRE); Royal Natal National Park, Pienaar 50 (PRE); Umgoye Forest Reserve, Van Rooy 146 (PRE); Xumeni Forest, Doidge CH10 (PRE); Weza Forest Reserve, Von Breitenbach s.n. (PRE). Limpopo: Entabeni Forest, Von Breitenbach $208 b$ (PRE); Serala Mountain, Von Breitenbach 136 (PRE); Westfalia Estate, Van Vuuren 1509 (PRE). Mpumalanga: Barberton, Oliver 7126 (PRE); Graskop, God's Window, Filter CH13410 (PRE); Mount Sheba Nature Reserve, Van Rooy 4207 (PRE); Sabie, Mac Mac pools, Cholnoky 635 (PRE, S). Western Cape: Bains Kloof, Esterhuysen 25589 (PRE); Constantia kloof, Sim 9344 (PRE); Kaaimans River W of Wilderness, Magill 6051 (PRE); Mitchells Pass, Magill \& Schelpe 4060 (PRE); Tsitsikamma National Park, Schelpe 7845, 7847 (PRE); Vogelgat Nature Reserve, Perold s.n. (PRE). Swaziland: Forbes Reef store, Magill 3534 (PRE); Mbabane, Kemp 857 (PRE). 